\title{
Tarihte Kaybolmuş Bir Medeniyet: Etrüskler ve Etrüsk Dini
}

\author{
Aynur Çınar*
}

\section{Öz}

"Etrüskler" MÖ. X-I. yüzyllar arasında İtalya'da yaşamış antik bir medeniyettir. Bu halk, Etrurya adını verdikleri vatanlarında muhteşem bir medeniyet kurmuş ve MÖ. 625-600 yıllarından itibaren Roma'nın temellerini atmıştır. Romalıların sistematik bir soykırımla yok ettiği bu halktan günümüze çok az şey kalmış ve XVIII. yüzylldan bu yana Etrüsk köken antropolojik olarak sürekli tartı̧ılmıştır. 2007'den itibaren Etrüsk köken ile Türkler ve Fenikeliler arasında kurulan bağlant, bu toplumu bizler için daha ilgi çekici bir hale getirmiştir. Etrüsklerin dinine bağlı olduğu en iyi bilinen gerçektir. Tarihçilere göre onlar, bir yandan rahatına düşün, kendine has bayramları olan, bu festivallerde içip dans etmeyi seven bir halk iken; diğer yandan melankolik, dindar, titizlikle uygulanan çeşitli ritüelleri olan ve kehânete önem veren bir halktır. Onların dini, antropomorfik politeizmdir ve bu din, kesin bir kaderci algiya dayanır. Ayrıca bu din kutsal kitaplara, peygamberliğe, sistematik bir ölüm ötesi anlayışına da sahiptir. Son olarak Etrüsk dininin çağdaşları olan Yunan ve Roma dinleriyle pek çok ortak noktasının bulunduğu bilinmektedir.

Anahtar Kelimeler: Etrüskler, Etrurya, Turan, fatum, Tin/Tinia, haruspice, Etrusca Disciplina.

\section{A Lost Civilization in the History: Etruscans and Etruscan Religion}

\author{
Abstract \\ "Etruscans" is an ancient civilisation which had lived in Italy between B.C.E. \\ X-I centuries. This people had established a magnificent civilisation in their home- \\ land whose name Etruria and as from B.C.E. 625-600 they had laid the foundations \\ of Rome. Very little information from this people which Romans had systematically \\ * Arş. Gör. Dr., Iğdır Üniversitesi, İlahiyat Fakültesi, Dinler Tarihi Bölümü, Iğdır/ \\ TÜRKIYE, aynur.cinar@igdir.edu.tr ORCID: 0000-0001-8576-7566 \\ Makale Gönderim Tarihi: 25.01.2018 - Makale Kabul Tarihi: 03.07.2018
}


carried out genocide has remained into the present and from XVIII. century until now Etruscan origin has been discussed consistently. Ever since 2007, relationship connected between Etruscan origin and Turks and Phoenicians have rendered this people appealing for us. It is the best-known fact that the Etruscans were religious people. According to the historians, in one sense Etruscans were self-indulgent, they had specific festivals, they liked to drink and to dance in these festivals; in another sense, they were religious and melancholic people, they had various rituals applied fastidiously, they valued prophecy. Etruscan religion was anthropomorphic polytheism and this religion was based on an exact fatalist understanding. Also, this religion had holy books, prophecy/prophethood and a systematic posthumous understanding. Finally, Etruscan religion have known that there were common grounds with its contemporaries, Greek and Roman religions.

Keywords: Etruscans, Etruria, Turan, fatum, Tin/Tinia, haruspice, Etrusca Disciplina

\section{Giriş}

Batı tarih anlayışının hâkim olduğu günümüzde, birtakım siyasi sebeplerle bazı halklar tarihte unutulurken, bazıları da unutulan halkların meziyetlerinden faydalanarak gereğinden fazla yüceltilir. Etrüskler, tarihte unutulmuş hatta ülkemizde ismi dahi pek bilinmeyen bu halklardan biridir. Bunun bir sebebi, Adile Ayda'nın da belirttiği gibi, Türk aydınlarının Türk ırkına ve Etrüskolojì ye dayalı meselelere ilgisiz kalmalarıdır. ' Türkiye'de Etrüsk çalışmaları genellikle bireysel bir çabayla yürütülmekte ve konuyla ilgili akademik çalışmaların ulusal ve uluslararası sahada kabul görmesi gerekmektedir. ${ }^{2}$ Diğer bir neden ise etnosentrik bakış açısına ve bilimsel tutuculuğa sahip Batı tarihçiliğinin Etrüskleri tarihî ve coğrafi yakınlık nedeniyle hep Yunan ve Roma medeniyetleri dahilinde hellenize etmeye çalışmasıdır. Bu yüzden Etrüsk adı Roma tarihi içerisinde erimiştir. ${ }^{3}$ Bu anlayışın

1 Adile Ayda, "Etrüsklerin Türklügüne Yeni Deliller", Atlantisliler Sümerler Etrüskler Türk mü.?, yay. Reha Oğuz Türkkan, Nokta Kitap, İstanbul 2012, s. 181. "Les Etrusques etaient-ile des Turcs" isimli bu tebliğ, Imprimerie Dauer (Paris 1971)'de yayımlanmıştır.

2 Akile Gürsoy, "Tarihten Bir Kesit: Etrüskler, Türkiye'de Türk Tarihini İncelemede Antropoloji'nin Katkısı", Tarihten Bir Kesit: Etrüskler Sempozyumu, TTK, 2-4 Haziran 2007 Bodrum, s. 47.

3 Vedia Izzet, The Archeology of Etruscan Society, Cambridge University Press, UK 2007, s. 10; Gürsoy, s. 53 . 
sonucu olarak Türk toplumu Etrüsklerin adını duymamış, duysa da ilgilenmemiş çünkü bu halkı kendinden kabul etmemiştir.

Etrüsk dini de tıpkı Etrüsk halkı gibi Yunan ve Roma dini bağlamında değerlendirildiği için dinler tarihinde müstakil bir alan işgal edememiştir. Hâlbuki kendine has unsurlar taşıyan Etrüsk dini, tıpkı medeniyeti gibi Avrupa toplumunu derinden etkilemiştir. Üstelik bu dinde ahiret, peygamberlik ve kutsal kitap gibi bazı unsurların bulunması da bu dinin evrensel nitelikleri bağlamında irdelenmelidir. Bu yüzden çalı̧̧mamızda bir parça Etrüskleri dinler tarihi perspektifinden tarihî, siyasî ve dinî bakımdan ele alacak biraz da Türk akademisine tanıtmaya ve hatırlatmaya çalışacağız.

\section{Etrüskler Kimdir?}

\section{a. Tarihte Etrüskler}

Etrüskler (Lat. Etruscus; İng. Etruscans), MÖ. X-I. yüzyıllar arasında İtalyaToskana' da ${ }^{4}$ yaşamış antik bir halktır. ${ }^{5}$ Bu toplumun kalıntıları üzerinde bulunan Toskana (İtal. Toscana, İng. Tuscany), günümüz İtalya'sının tam merkezinde yer alan ve Avrupa Rönesans hareketine ev sahipliği yapan önemli bir merkezdir. ${ }^{6} \mathrm{Bu}$ topraklarda kendilerine Rasena diyerek dişi bir kurdun çocukları olduklarına inanan Etrüskler ${ }^{7}$, çağdaşlarınca Tirhenler (Tun. Tyrsenoi/Tyrrhenoi) ve Etruski-Turski/Turşa/ Tuski şeklinde anılıyorlardı. Dönem itibariyle "Etrüsk" adı Mısır kayıtlarında Turuşka veya Tursk şeklinde geçer. Fakat bu kullanım Yunancada "t-r-r" ünsüzleriyle ve $h$ harfinin $a$ 'ya dönüşmesiyle teleffuz edilince, isim Yunanca "Turan" anlamina yirmi bölgeden biridir.

5 Titus Livius (Livy) Patavinus, The Early History of Rome, trans. Aubrey De Sélincourt, Penguin Books, 2002, I-V, 16; Larissa Bonfante-Judith Swaddling, Etrüsk Mitleri, çev. Birgül Açıkyıldız, Phoenix Yayınları, Ankara 2006, ss. 11-12; Peter Chrisp, Atlas of Ancient Worlds, DK, New York 2009, s. 32; Firudin Ağasığlu (Celilov), Etrüsk Türk Bağı, sad. Hüseyin Adıgüzel, Bilge Oğuz Yayınları, Ankara 2013, s. 16.

6 http://global.britannica.com/EBchecked/topic/610528/Tuscany (Erişim Tarihi: 02.12.2014).

7 Ayda, a.g.m., s. 188. 
gelen Turrhnoi-Tyrrhenoi șekline dönüşmüștür. ${ }^{8}$ Yine Tirhen/Tiren Denizi (Tyrrhenian Sea) ve Toskana isimlerinin de aynı etimolojik kökene sahip olduğu bilinmektedir. ${ }^{9}$

MÖ. VIII-V. yüzyıllar arası, Etrüsk medeniyetinin altın çağıdır. ${ }^{10}$ Bu dönemde Etrüskler, Etrurya (E-Turia) ${ }^{11}$ adını verdikleri yurtlarında teokratik yönetime dayalı on iki site devletinden müteşekkil federe bir yapı kurdular. ${ }^{12}$ Roma tarihçisi Livy'ye göre bu devletin ünü ve ihtişamı, o zamanlar Alp dağlarından Messina boğazına kadar bütün kara ve denizlere yayıldı. ${ }^{13}$ Eskiden medeniyetten yoksun olan Toskana'y $1^{14}$ Etrüskler doğaya saygllı şekilde imar ettiler; sulama sistemleri yaptılar, bataklıkları kuruttular, tarımı güçlendirme amaçlı geri dönüşüm drenajları ve görkemli yapılar inşa ettiler, maden ocakları vasıtasıyla maden işçiliğinde mahir hale geldiler. ${ }^{15}$ Sanatçı ruha sahip bu halktan geriye pek çok mimari yapı, duvar resmi, süsleme, kil/çamur veya bronz heykel kald. ${ }^{16}$ Günümüzde Louvre, British gibi dünyanın ünlü müzelerini süsleyen çok sayıdaki sanat eserinin Etrüsk mezarlarından geldiği bilinmektedir. ${ }^{17}$ Aynı zamanda denebilir ki Roma'dan itibaren günümüz modern Avrupası alfabesinden, sanatına ve mimarisine, devlet yönetiminden askeri yapısına kadar pek çok şeyi Etrüsklere borçludur. ${ }^{18}$

Etrüsk kelimesinin detaylı etimolojisi için ayrıca bkz; Mustafa Solmaz, "Biçimbilim ve Sözdizim Açısından Etrüsk Dili", IYÜ Sosyal Bilimler Enstituisü (basılmamış yüksek lisans tezi), Van 2005, ss. 4-5; Reha Oğuz Türkkan, Atlantisliler Sümerler Etrüskler Türk mü??, Nokta Kitap, İstanbul 2012, ss. 153-154.

9 H. H. Schullard, A History of the Roman World, Routledge, New York 1980, s. 25; Bonfante-Swaddling, ss. 11-12.

10 Dominique Briquel, "Etruscan Religion", Encyclopedia of Religion, by. Lindsay Jones, Ind edition, (1987) 2005, V, 2870.

11 Türkkan Etrurya adını, "Türk-eli” olarak izah eder. Bkz; Reha Oğuz Türkkan, "Türk Tarih Tezleri”, Türkler Ansiklopedisi, edt. Hasan C. Güzel ve diğerleri, Yeni Türkiye Yayınları, Ankara 2002, I, s. 413.

12 Titus Livius, Livy's Hannibal's War, trans. J. C. Yardley and Dexter Hoyos, Oxford World's Classics, USA 2006, XXII/3, s. 69; H. H. Scullard, A History Of The Roman World, Routledge, Vth edt., ABD 1980, s. 25; Gürsoy, a.g.m., s. 42; Ağasığlu, a.g.e., s. 16.

13 Livy, The History of Rome, trans. Valerie M. Warrior, Cambridge 2006, Kitap I, ss. 7-8.

14 Leonardo Rombai, "The Natural Environment", The Land Of The Etrucans, edt. by. Salvatore Settis, Scala Books, Italy 1985, s. 5; Chrisp, a.g.e., s. 42; Ağasığlu, a.g.e., s. 32.

15 R. M. Ogilvie, Early Rome And The Etruscans, Harvester Press, Fontana, 1976, ss. 30-31; Türkkan, a.g.m., I, 416; Chrisp, a.ge., s. 42; Rombai, a.g.m., ss. 6-7; Encyclopedia of World History, I, 139; Bonfante-Swaddling, a.g.e., s. 12.

16 Ogilvie, a.g.e., s. 31; Schullard, a.g.e., s. 29; Chrisp, a.g.e., s. 42.

17 Adile Ayda, Etrüskler Türk mü idi?, TKAE, Ankara 1974, s. 8; Bonfante-Swaddling, a.g.e., s. 13.

18 Fatma İpek Ek ve Deniz Şengel, "Mısır, Etrüsk, Roma: Piranesi ve Bir On Sekizinci Yüzyıl 
Livy'nin güçlü, açıkgöz ve girişken bir toplum olarak tanımladığı Etrüskler, MÖ. 625-600 yıllarında Roma'yı kurdular, Akdeniz'e hükmettiler. ${ }^{19}$ Etrüsk asilleri o dönemlerde çok geri kalmış bir şehir olan Roma’ya yerleşip MÖ. 616-509 yılları arasında burayı yönettiler. ${ }^{20}$ Dumézil'e göre bu bir asırlık dönemde Roma halkı Etrurya hegemonyası altında oldukça refah bir hayat sürdü. ${ }^{21}$ Bu sayede Roma, henüz kuruluş aşamasında devlet teşkilatı, hukuk, ordu, sanat ve daha pek çok alanda Etrüskleri model alarak geleceğin en büyük imparatorluğu haline geldi. ${ }^{22}$ Ne var ki MÖ. 509'da aristokratlara (patricians) karşı ayaklanan halk tabakası (plebians) Etrüskleri Roma'dan kovdu ve cumhuriyeti kurdu. MÖ. IV. yüzyıldan itibaren Romalılar "mavi kanlı" ’23 olduklarına inandıkları Etrüsklere büyük bir nefretle saldırdılar ve tüm halkı kılıçtan geçirdiler. ${ }^{24}$ Ardından MÖ. 480'de Büyük Yunan Birliği’ne (Magna Graecia) yenilen Etrüskler, bir daha eski günlerine dönemediler ve aralarında tam bir siyasi birliğin kurulamamış olması hasebiyle kaderlerini Roma'ya teslim ettiler. ${ }^{25}$ Romalılar da kendilerine önderlik etmiş bu halka dünya tarihindeki ilk sistemli soykırımı uyguladı. ${ }^{26}$

Roma soykırımından sonra asırlarca dünya Etrüskleri hatırlamadı. Ortaçağın sonlarına Etrurya topraklarında kipırdanan Rönesans'la hareketin öncüleri olan sanatçı ve bilim adamları Etrüsklerin din, dil, devlet ve ritüellerine merak sardılar ve bu konularla ilgili eserler kaleme aldılar. Netice olarak 1726'da Cortona'da

Tartışması", METU JFA, 2008/1 (25:1), s. 27; Ağasığlu, a.g.e., s. 13.

19 Livy, The Early History, Kitap I, s. 35.

20 Ogilvie, a.ge., s. 30; Ayda, a.g.e., s. 11; Livy, The Early History, Kitap I, s. 22. Söz konusu hâkimiyet dönemi kronolojik olarak şöyledir: MÖ. 617-578’da Kral Tarquinius Priscus, 578-535’te Kral Servius Tullius ve 535-510'da Kral Tarquinius Superbus Roma kralı olmuştur. Ayrıntılı bilgi için bkz; Ayda, a.g.e., s. 11; Livy, The History, s. XXXIII; Livy, The Early History, Kitap I, 17; Briquel, a.g.m., V, 2870.

21 Georges Dumézil, Archaic Roman Religion With an Appendix on the Religion of Etruscan, trans. by. Philip Krapp, The John Hopkins Univ. Press, Chicago 1996, I, 11.

22 Ogilvie, a.g.e., s. 33; Ayda, a.g.e., s. 8; Gürsoy, a.g.m., s. 43; Türkkan, a.g.m., I, 416; Chrisp, a.g.e., s. 42.

23 "Mavi kan", Avrupa'da asil soydan gelenler için kullanılan bir tabirdir. Mel Copeland, Work Notes on Etruscan Language, 2012, s. 1.

24 Bkz; Schullard, a.g.e., ss. 34-35; Titus Patavinus Livy (Livius), Rome's Mediterranean Empire, trans. Jane D. Chaplin, Oxford University Press, New York 2007; ss. 231-233; Encyclopedia of World I, xxxiii; Mel Copeland, Work Notes on Etruscan Language: https://www.academia.edu/1808299/ Introduction_to_the_Etruscan_language_-_a_compilation_of_Work_Notes_with_Glossary, 2012. (Erişim Tarihi: 25.01.2018) s. 2.

25 Ağasıŏlu, a.g.e., ss. 33, 35.

26 Ayda, a.g.e., ss. 15-16. 
kurulan Etrüsk Akademisi (The Accademia Etrusca) ile Etrüsk çalışmaları akademik nitelikle resmen başlamış oldu. ${ }^{27}$

\section{b. Etrüsklere Köken Belirleme Çabası}

Etrüsklerin kökeni konusundaki Batılı anlayış, genellikle, onları Sümerler gibi tarihte kesin olarak akrabası bulunmayan yalnız bir halk olarak tanımlama eğilimindedir. ${ }^{28}$ XVIII. yüzyıldan bu yana yürütülen akademik çalışmalarda Etrüsk köken sürekli tartışılmış, dili deşifre edilemediği için efsaneleştirilerek ${ }^{29}$ onlara " $G i$ zemli Etrüskler" denmiştir. Bu sebeple Etrüsklerin anavatanı, kökeni ve dilleri hakkında gündeme gelen bütün spekülasyonlar, Etrüsk esrarını çözme çabasının bir ürünü olarak görülebilir. ${ }^{30}$ Pek çok Etrüskolog, bu toplumun özgünlüğünden yola çıkarak bu halkın kökeniyle ilgili birtakım varsayımlar üretmiştir. ${ }^{31} \mathrm{Bu}$ varsayımlar genellikle Etrüsklerin "otokton/yerli" veya "göçmen" bir halk olduğu gibi farklı yönlerde olsa da ${ }^{32}$ yeni bulgular ışı̆̆ında biz bunları üç grupta değerlendirebiliriz:

Etrüskler İtalya'nın en kadim öz halkıdır ve İtalya'ya yerleşen Hint-Avrupalı göçmenlerle karışarak Romalılar oluşturmuşlardır. ${ }^{33} 1947$ 'de arkeolog Massimo Pallottino, İtalyaBologna yakınlarındaki Villanova'da MÖ. 1600-1200 arasında Hint-Avrupa dillerinden farklı bir dil konuşan yerli bir halka rastladı ve adını Villanovan koyduğu bu halkı proto-Etrüsk olarak isimlendirdi. ${ }^{34}$ Pallottino'nun tezi uzun süre ortodoks Etrüskoloji doktrini olarak kabul edildi. ${ }^{35}$ Fakat ilkel Villanovan halktan birdenbire Etrüsk sanat ve estetiğine geçilemeyeceğini düşünenler, bu iddiaya karşı çıkarak aşă̆ıdaki varsayımlara sarıldılar. ${ }^{36}$

27 Nancy Thomas de Grummond, "Introduction: The History of the Study of Etruscan Religion", The Religion of the Etruscan, edt.by. Nancy Thomas de Grummond-Erica Simon, University of Texas Press, Texas 2006, s. 4.

Gürsoy, a.g.m., s. 42; Ağasığlu, a.g.e., s. 7.

29 Bonfante-Swaddling, a.g.e., s. 11.

30 Scullard, a.g.e., s. 25.

31 Ayrıntılı olarak bkz; Philip Perkins, "DNA and Etruscan Identity", Etruscan by Definition: Papers in Honour of Sybille Haynes, The British Museum Research Publications, London 2009, s. 95.

32 Dumézil, a.g.e., s. 629.

33 Türkkan, a.g.e., s. 152.

34 Ayda, a.g.e., s. 10; Schullard, a.g.e., s. 26; Encyclopedia of World, I, 139; Türkkan, a.g.m., I, 417; Marisa Bonamici, "The Etruscan Period", The Land Of The Etrucans, edt. by. Salvatore Settis, Scala Books, Italy 1985, s. 12; Bonfante-Swaddling, a.g.e., s. 11.

35 Perkins, a.g.m., s. 95.

36 Schullard, a.g.e., ss. 25-26; Türkkan, a.g.m., I, 416; Ağasıoğlu, a.g.e., s. 15. 
Etrüskler, Türklerle ayn kökene sahiptir ve anavatanlan Anadolu'dur. Anadolu topraklarından İtalya'ya farklı tarihlerde farklı gerekçelerle göçler gerçekleştiği bilinmektedir. Uzun süre bilim çevrelerince itibar edilmeyen Herodot'un aktarımlarına göre, çıkan kıtlık sebebiyle MÖ. XIII. yüzyıldan itibaren birkaç dalga halinde Anadolu'dan Toskana'ya göçler gerçekleşmiştir. ${ }^{37}$ Bu göçlerin bahsi Firavun Merneptah kitabesinde dahi kaydedilmiş ve göç eden halklar arasında Truvalılar Turşa olarak anılmıştır. Bu bağlamdaki diğer bir görüşe göre de Etrüskler, Doğu ve Batı dünyasını stratejik olarak ilk kez karşı karşıya getiren MÖ. XIII. yüzyıl Truva boğaz savaşı sonucu anavatanlarını işgal eden Akhalardan kaçarak Toskana`ya göçen Truvalıların torunlarıdır. ${ }^{38}$ Öte yandan K. Mirşan ve ekibinin dile getirdiği Etrüsklerin biri Anadolu'dan (Turlar) diğeri de Karadeniz'in kuzeyinden (Sakalar) İtalya'ya göçen iki farklı Türk boyunun torunları olduğu iddiası, her iki tarihi kaydın arkaplanını açıklaması bakımından değerlidir. ${ }^{39}$ Benzer bir görüşü benimseyen Türkkan, Etrüsk ve Türk kökenli Truvalıların Pelaj (Pelasg) koluna bağlı olduklarını ve Villanovon halka birleşerek Etrüsk halkının oluşmuş olabileceğini söyler ${ }^{40}$ ki bu, aynı zamanda Anadolu'daki Türk varlığının oldukça kadim zamanlara dayandığının işaretidir. Etrüsklerin Pelasg atalara bağlı olduğunu söyleyen bu görüş, Herodot'un "Pelasglar, Tirhen (Tyrrheni) Denizi'nin üstündeki Cortona (Toskana)'da oturanlarla aynı dili konuşurlar" ${ }^{\prime \prime}$ şeklindeki ifadesiyle uyum sağlar. Etrüsklerin Lidya ve Anadolu kökeni iddiasının lengüistik açıdan Fransız arkeolog G. Cousin ve F. Durrbach tarafından ispatlandığını belirten Dumézil ise onların Hitit kökenli olabileceğini iddia eder. ${ }^{42}$

Moleküler genetik, arkeolojik ve antropolojik pek çok çalışmada da birbirine yakın bulguya rastlanır. Antropolojik olarak dönem itibariyle oldukça karışık bir etnisiteye sahip Etrurya'da dört farklı ırk tipi tespit edilmiştir. Bunlardan asilzade-

37 Schullard, a.g.e., s. 25; Encyclopedia of World, I, 139; Türkkan, a.g.e., ss. 166-168; Martin Bernal, Kara Atena, çev. Özcan Buze, Kaynak Yayınları, İstanbul 2014, s. 562.

38 Encyclopedia of World, I, 139; Perkins, a.g.m., s. 95; Copeland, a.g.m., s. 2; Ekrem Memiş, "Etrüsk Kavminin Oluşumunda Troyalılar'ın ve İskitlerin (Sakalar) Rolü”, Tarihten Bir Kesit: Etrüskler Sempozyumu, TTK, 2-4 Haziran 2007 Bodrum, ss. 107-108; Ağasığlu, a.g.e., s. 25.

39 Ahmet Arslan ve diğerleri, "Archeological, Etymological, and Genetic Traces of Migrations Along with Etruscan Migration for Forming European Nations: I. Migrational Traces Was Followed Together with Alphabetical Evolution", Tarihten Bir Kesit: Etrüskler Sempozyumu, TTK, 2-4 Haziran 2007 Bodrum, s. 103; Memiş, s. 109.

40 Türkkan, a.g.m., I, 417; a.g.e., s. 153; Gürsoy, a.g.m., ss. 44-45.

41 Herodotus, trans. by. A. D. Godley, Harvard Univ. Press, London 1975, I: 57.

42 Dumézil, a.g.e., ss. 629-632. 
lere ait olan, Türklerin de ait olduğu yuvarlak kafataslı brakisefal (Homo Alpinus) irk tipidir. Ayrıca Etrüsk döneme ait pek çok heykelde dikkati çeken şey, bu bulguyla doğru orantılı olarak, tiplerin asiatik insan tipine uygun oluşudur. ${ }^{43}$ Ayrıca Etrüsklerin hayvan heykeli tarzlarının İskit ve Altay Türklerinin sanat anlayışı ile olan benzerliği de bir diğer kanıt olarak görülebilir. ${ }^{44}$

Yine Dr. Vernesi ve bilim ekibinin yaptığı genetik araştırmada, Etrüsklerin Anadolu'dan geldiği ve DNA yapılarının Türklerle büyük bir benzerlik taşıdığı ortaya çıkmıştır. ${ }^{45}$ Dünya medyasının ilgisini çeken bu haber, antik tarihçilerin zaferi olarak kaydedilmiş ve 'ön-Türk' Etrüskler, Truvalıların halefi ilan edilmiştir. ${ }^{46}$

Etrïsklerin genetik yapılarn Afro-Asyallarla uyumludur ve Misir-Fenike kökenlidir. Dr. Pellechia ve departmanı tarafindan yapılan ikinci bir genetik araştırmaya göre Etrüsk DNA'sı, Türklerin yanı sıra Kuzey Afrika DNA'sı ile de uyumludur. ${ }^{47} \mathrm{Bu}$ varsayım, bilhassa antik Levant, Yunan ve İtalyan kemik yapılarının Fenikelilerle benzerliğinden yola çıkılarak ortaya konulmuştur. ${ }^{48}$ Yanı sıra Avrupa'da bir eşi daha bulunmayan Etrüsk duvar resimlerinin Mısır sanat anlayışına yakınlığı da bu iddiayı güçlendirmektedir. ${ }^{49}$

Bütün bunlardan sonra Etrüsklerin, Villanovon halkla karşsan Türk ve Kipti-Fenike kanşımı melez bir halk olduğu söylenebilir.

43 Türkkan, a.g.e., ss. 158-161.

44 Solmaz, a.g.t., s. 5; Gürsoy, a.g.m., s. 46.

45 Cristiano Vernesi ve Diğerleri, "The Etruscans: A Population-Genetic Study”, Am 7 Hum Genet, 2004 April;74 (4): 694-704. Ayrıca bkz.; Erkan Ildız, "Roma Uygarlığının Kökenindeki Doğu Etrüskler”, Atlantisliler Sümerler Etrüskler Türk mü?, yay. Reha Oğuz Türkkan, Nokta Kitap, İstanbul 2012, ss. 193. Bu makale Bilim ve Ütopya Dergisi (Aralık 2005, Sayı: 138)'den alınmıştır.

46 Encyclopedia of Wars, s. 446; Perkins, a.g.m., s. 95. Ayrıntılar için bkz; http://www.theguardian.com/world/2007/jun/18/italy.johnhooper; http://www.newscientist.com/article/ dn11174-on-the-origin-of-the-etruscan-civilisation.html; http://www.telegraph.co.uk/news/ uknews/1542903/Genes-prove-Herodotus-right-about-Etruscans.html; http://www.nytimes. com/2007/04/03/science/03etruscan.html (Erişim Tarihi: 04.12.2014). Ayrıca bkz; Türkkan, a.g.m., I, ss. 409-423.

47 Perkins, a.g.m., s. 99; Marco Pellecchia ve Diğerleri, "The Mystery Of Etruscan Origin: Novel Clues From Bos Taurus Mitochondrial DNA", Proceedings of The Social Society B, Royal Society Publishing, http://rspb.royalsocietypublishing.org/on December 5, 2014, pp. 1175-1179.

48 Robert Ellis, The Armenian Origin Of The Etruscan, Biblioteca Bodleiana, London 1861; s. 30; Perkins, a.g.m., s. 96; Bernal, a.g.e., s. 557.

49 Etrüsk ve Mısır sanat anlayışlarının benzerleriyle ilgili geniş bilgi için bkz. Ek ve Şengel, ss. 27-51; Elif Tül Tulunay (İstanbul Üniv. Edebiyat Fak. Klasik Arkeoloji A.B.D. Öğr. Üy.)'dan aktarım, Türkkan, a.g.e., s. 229. 
Etrüsk köken gibi bu halkın dil yapısı da karmaşıktır. Çünkü Roma soykırımıyla Etrüsk dili de tarihe karışmıştır. Bu da Etrüsk kültürü ve dini hakkında net bir çalışma yapma şansını azaltmaktır. ${ }^{50}$ Her şeye rağmen 26 karakterden oluşan ve alfabe sürecini yakalamış olan Etrüskçe hakkında günden güne artan çözümlemeler, onların dil yapısı hakkında fikir vermektedir. ${ }^{51}$ Ağasığglu'na göre Etrüsk dili, Sümerceye benzemekle birlikte yerel dillerin etkisiyle oluşan karmaşık bir yapıya sahiptir. ${ }^{52}$ Kimi Türk dil bilimciler konuyu daha da netleştirerek Etrüskçenin proto-Türkçeden doğan ve köken olarak MÖ. III. binylldan daha eskiye uzanan bir dil olduğunu gösteren bilimsel çalışmalar yapmışlardır. ${ }^{53}$ Buna göre Etrüskçe, eklemeli yapısı, artikelsizliği, sıfat öncelemesi, fiil çekimlerinin edatlarla yapılması ve cümle kurulumu bakımından Ural-Altay dilleriyle benzerdir. ${ }^{54}$ Dahası 26 alfabe karakterinin 10'unun birebir aynı olması hasebiyle Etrüsk ve Göktürk alfabesi kardeştir. ${ }^{55}$ Etrüskçede $g, d$ ve $b$ gibi yumuşak sessizler olmadığı için, bu harflerin kullanıldığı yabancı kelimeler $k, t$ ve $p$ sert sessizlerine dönüştürüp yazılır. Yine bu alfabede $a, e, i$ ve $u$ olmak üzere sadece dört tane sesli harf bulunur ve $o$ sesi her zaman $u$ 'ya çevrilir. Son olarak Etrüsk dilinde cinsiyet ayrımının olduğu ve eril isimlerin sonuna $-e$, dişil isimlerin sonuna da $-a$ ve $-i$ seslisi eklendiği bilinmelidir. ${ }^{56}$ Etrüsklerin, Yunan alfabesini kendi gramerlerine uyarladıkları iddia edilse de ${ }^{57}$ Yunanlıların aksine sağdan sola doğru yazılan Etrüsk alfabesi, Latin alfabesinin temelini atan ve kuzey halklarınca kullanılan runik alfabenin devamı olarak görülmektedir. ${ }^{58}$

\section{Etrüsk Dini}

"Din, Etrüsk medeniyetinin en iyi bilinen yönüdür" diyen arkeolog Pallottino, Etrüsk arkeoloji kazılarından edindiği izlenimi belirtir. ${ }^{59}$ Bu ifade, her antik

Dumézil, a.g.e., ss. 625-628.

İsmail Doğan, "Etrüsk Yazısının Kaynağı: Türk (Göktürk) Yazısı", Tarihten Bir Kesit: Etrüskler Sempozyumu, TTK, 2-4 Haziran 2007 Bodrum, s. 170.

Ağası̆ğlu, a.g.e., s. 17.

Ayrıntılı bilgi için bkz. Ahmet Arslan ve diğerleri, ss. 65-105.

Türkkan, a.g.m., I, 418; Türkkan, a.g.e., s. 155.

Doğan, a.g.m., s. 171.

Bonfante-Swaddling, a.g.e., ss. 17-18; Etruscan Glossary, pre.by. Mahir Ünsal Eriş, Ankara 2005; Solmaz, a.g.e., ss. 16-17.

Encyclopedia of World History, I, 139; Bonfante-Swaddling, a.g.e., s. 13.

Türkkan, a.g.e., s. 169; Gürsoy, s. 43.

De Grummond, "Introduction", s. 1. 
toplumda karşlaşılan din ve sosyal hayatın bütünselliği şeklinde yorumlansa da Livy'nin, "Bu insanların çoğu kendini dinî meselelere vakfetmişti" sözü, Etrüsk dindarlığının karakteristik olarak antik toplumlar arasında ne kadar sivrildiğinin işaretidir. Etrüskler bir yandan kendine has bayramları ve festivalleri olan ve içip dans etmeyi seven ve erotizm düşkünü şeklinde tanımlanırken; diğer yandan melankolik, dindar, ritüellerinde titiz ve kehânete önem veren bir halk olarak bilinir. ${ }^{60}$ Onlarda da tıpkı Hinduizm ve Yahudilikteki gibi nesebe bağlı dinî bir kast ve bu kastın zirvesinde özel güçlerle donandığına inanılan din adamlarının bulunması, Etrüskleri doğu inanç dünyasına yakın kılar. ${ }^{61}$

Etrüsk dinini, mitlerini ve panteonunu anlamada en büyük kaynaklar duvar resimleri, tapınak sunakları ve ayna-vazo oymacılığı gibi sanatlardır. Etrurya tapınaklarında bulunan nesne ve kitabeler bu halkın medeniyeti ve dini hakkında bize rehberlik eder. ${ }^{62}$ Etrüsklerin şehirlerini, fas adını verdikleri ilahî yasanın emrettiği şehir planına uygun kurmaları, teoloji ve mimari anlayışları arasında köprü kurulduğunu gösterir. Onlar kuracakları her şehrin tespit edilen bir noktasına kutsadıkları bir duvar örerler ve etrafinı harem kıldıkları bu bölgede (pomerium) iskân ve ziraati yasaklarlardı. Şehir genişledikçe kutsanan sınır taşını daha ileriye taşıyarak şehrin korumasını artırırlardı. ${ }^{63}$ Tapınaklarını da Yunan ve Roma geleneğine benzer şekilde bir cephesini yüksek sütunlardan oluşan dörtgen yapılar şeklinde kutsal metinleri Etrusca Disciplina uyarınca imar ederlerdi. Tüm mimari yapıları simetrik hesaplarla kapıları doğuya gelecek şekilde inşa edilmiştir. Bu, Etrüsklerin muhtemelen Mısır anlayışından devraldıkları simetri tutkusu olup Romalılara miras kalarak Avrupa şehir mimarisini etkilemiştir. ${ }^{64}$ Aynı tutku yön algılarına da yansımış ve tanrıların önem sırasına göre şehirlerini altı yöne (kuzey, güney, doğu, batı, aşağı, yukarı) ayırmışlar ve tüm ritüellerini bu doğrultuda gerçekleştirmişlerdir. ${ }^{65}$

60 Scullard, a.g.e., ss. 27, 30; Briquel, a.g.m., V, 2870; Ağası̆̆lu, a.g.e., s. 34.

61 Thomas Keightley, The Mythology of Ancient Greece and Italy, Whittaker Co., Ind edition, London 1888, ss. 503-504.

62 Erika Simon, "Gods in Harmony-The Etruscan Pantheon", The Religion of the Etruscan, edt. by. Nancy Thomas de Grummond-Erica Simon, University of Texas Press, Texas 2006, s. 45; Bonfante-Swaddling, a.g.e., ss. 15-16.

63 Livy, The History, ss. 63-65.

64 Schullard, a.g.e., s. 29.

65 Riccardo Francovich, "The Middle Ages", The Land of the Etruscans from Prehistory to the Middle Ages, edt.by. Salvatore Settis, Scala Books, Italy 1985, s. 42. 


\section{a. Etrüsk Tanrı Anlayışı ve Panteonu}

Etrüsk dini antropomorfik politeizmdir, dolayısıyla bir panteona sahiptir. Etrüskler deniz, ırmak, dağ, gök, yıldırım gibi doğa olaylarına ruh atfederek bunları tanrılaştırmışlardır. Bu sebeple dinlerinin kökeninde, diğer antik dinler gibi, natüralist ve animist nitelikler bolca bulunur. Bu inanç sisteminde genel olarak "tanrı" kavramı Âsar (Lat. Æsar) kelimesiyle ifade edilir. ${ }^{66}$ Asar, muhtemelen Yunan din ve felsefesini derinden etkileyen ve nur ve hava bütünselliği bağlamında Zeus'la eşitlenen en yüce tanrısallık boyutu aither'in Etrüsk dinindeki yansıması olabilir. $^{67}$

Etrüsk tanrı anlayışı iki katmanlıdır: Bunlardan ilki, antropomorfik niteliklerden uzak, adı ve varlığı gizli olan, mutlak ve aşkın en yüce tanrıdır. Panteonun ikinci katmanında gizli olan bu tanrının kendini doğaya yansıtan farklı tezahürlerinden oluşmuş insani nitelikleri haiz altı tanrı, altı da tanrıça olmak üzere on iki tanrının bulunduğu bir panteon yer alır. ${ }^{68} \mathrm{Bu}$ on iki tanrının her birinin kendisine ait bir doğa olayı, kutsal yönü, tecellisi vardır ve hepsi birden On İki Boylu Etrüsk Birliğinni oluşturur. ${ }^{69} \mathrm{Bu}$ birliğin en yüce tanrısı Tinia, fenomenler dünyasındaki geçerli yasadan sorumludur. Fakat ne olursa olsun tek başına karar verecek kadar aşkın sayılmadığı için evrensel yasada herhangi bir değiş̧iklik yapacağı zaman alt tanrılar meclisini toplayarak onlara başkanlık eder. ${ }^{70}$ "Birlikte yaşayıp birlikte ölenler (Consentes/Complices)" anlamindaki tanrılar meclisi ${ }^{71}$, Etrurya'nın her biri farklı tanrının yönettiği on iki budunluk siyasal birliğini oluşturur ki bu da Etrüsk teolojisinin siyasete bir yansımasıdır. Evrendeki 'yaşam (oluş)' ve 'ölüm (bozuluş)'e dair her olay, bu tanrılar meclisinin hükmünce gerçekleşen bir "kader (fatum)" dir. ${ }^{72}$ Tanrılar meclisinden çıkan bütün fatum'lar kutsal yasa (lex sacrata) olarak adlandırılır. Laik ögeler içeren Yunan dininin aksine Etrüsk dininde Tanrı ve insanın konumu kesin çizgilerle ayrıldığı için insana düşen, tanrıların hükümlerine boyun eğmek-

Ağasığlu, a.g.e., s. 37.

Aither' in Zeus olarak Yunan din ve felsefe geleneğine yansımaları için bkz. Peter Kingsley, Antik Felsefe Gizem ve Büyü (Pythagoras ve Empedokles Geleneği), çev. Kenan Kalyon, Kabalcı Yayınları, Istanbul 2002, ss. 25-45.

Ogilvie, a.g.e., s. 35; A ğasığlu, a.g.e., s. 38.

Livy, The Early History, Kitap I, s. 40; Schullard, a.g.e., s. 33.

Ağasığlu, a.g.e., s. 45.

Keightley, a.g.e., s. 504.

Simon, a.g.m., s. 48. 
tir. ${ }^{73}$ Kutsal yasaya uymayan bir halk, "tanrların gözünde lanetlenir" ve yok olmaya mahkûm edilir. Yazgısını değiştirmeye ve hükmü çiğnemeye çalışanlar, ilahî yasaya aykırı hareket eder ve meclis tanrılarını gücendirir. ${ }^{74}$ Bazı Etrüsk mit ve sanatında fatum'u kabullenemeyenlerin başına gelen akibet, ibretle betimlenmiştir. ${ }^{75} \mathrm{Bu}$, ölümün günahkârlıkla özdeşleştirildiği kadim anlayışın bir tezahürüdür. Tanrılar, insanlarda olduğu gibi uygarlıkların ömrüne dair fatum da belirler. Bu yazgıda toplumlara biçilen ömür on saeculalık (yüzylllık) süreyi geçmez. ${ }^{76}$ Ortalama 119-123 ylla tekabül eden saecula (Lat. Saeculum), insan, şehir veya devlet yapısının ömrünü ve neslin yenilenme süresini hesaplamak için Etrüsklerce icat edilen ve onların da tanrılarına dayandırdığı bir zaman hesabıdır. ${ }^{77}$ Saecula kavramı daha sonra Romalı tarihçiler tarafından kendi tarih kayıtlarını dönemlere ayırmak için kullanılmıştır.

Panteon tanrıları, Etrüsk semalarında yaşar. Tanrılar Etrüsk federal devlet yapılanması esas alınarak ve ek bölgeler dahil edilerek on altı gök bölgesine göre konumlanmışlardır. Bu tanrıların yerini en iyi, kendilerine Haruspis (Haruspice) adı verilen Etrüsk kâhinleri bilir. Gökte yaşayan ve kutsal yasaya göre gökleri ayakta tutan bu tanrılara kurbanlar sunulur. Ayrıca belli mekânlara atfedilen tanrılar, kimi zaman yüce kâhinin kült yerini değiştirmesiyle yeni bir uğrak alana yerleşebilir. ${ }^{78}$

Etrüsk tanrı adlarının birçoğu Yunan tanrılarıyla özdeştir. Bu bakımdan panteonu anlayabilmek için Yunan diniyle karşılaştırmak gerekebilir. Bu sebeple Etrüsk dinin Yunan dininden bir istifade olduğu iddia edilmiştir. ${ }^{79}$ Keightley bu benzerliği, Etrüskler ve Yunanlılar arasında ticari ilişkilere bağlar. ${ }^{80}$ Nitekim bu iki halk aynı coğrafyanın çocukları olduğundan benzer din ve mitolojilere sahip olmaları gayet normaldir. Dolayısıyla bunu taklitçilikle karıştırmamak gerekir.

73 Encyclopedia of World History, I, 139.

74 Livy, The Early History, Kitap IV, s. 287, 69. dipnot.

75 Bunun en güzel örneği Thebai mitidir. Aslen bir Yunan miti olan Thebai Döngüsü, bir kâhinin haber verdiği kaderi değiştirmeye çalışan Thebai Kralı Laios ve hanesinin üç kuşak boyunca başına gelen felaketleri anlatır. Bkz; Bonfante-Swaddling, a.g.e., ss. 37-46.

76 Schullard, a.g.e., s. 31.

77 Simon K. F. Stoddart, Historical Dictionary of the Etruscans, The Scarecrow Press, UK 2009, s. 170; Briquel, a.g.m., V, 2873.

78 Simon, a.g.m., s. 45.

79 De Grummond, "Introduction", s. 1; Encyclopedia of World History, I, 139; Keightley, a.g.e., ss. 504-505; Simon, a.g.m., s. 46; Briquel, a.g.m., V, 2871 ; Bonfante-Swaddling, a.g.e., s. 17.

80 Keightley, a.g.e., s. 505; Schullard, a.g.e., s. 31; Bonfante-Swaddling, a.g.e., s. 102; A ğasıoğlu, a.g.e., s. 32 . 
Zira öncelikle Etrüskler bu mit ve inanışları büyük ihtimalle eski anavatanlarından devralmışlar yani birçoğunu kendileri üretmişlerdir. Hatta Yunan kültürünün bir ürünü kabul edilen İlyada bile Truva'yı işgal eden Akha kökenli Helenlerden ziyade Etrüsklerin öz ataları Truvalıları konu alması bakımından onlara ait kabul edilebilir. ${ }^{81}$ Ayrıca özgün bir zekayla medeniyet üreten Etrüsklerin, Yunan dinine benzer unsurları kendi dinî-kültürel algılarına göre yeniden yoğurdukları ve çok farklı bir teoloji ürettikleri araştırmanın ilerleyen bölümlerinde görülecektir. Onlar, benzer kavram ve karakterlere yeni anlamlar yükleyerek bambaşka bir din tesis etmişler $^{82}$ ve aynı ada sahip tanrıları kendi teolojilerine göre farklı niteliklerle tarif etmişler hatta panteonlarına yeni millî tanrılar dahil etmişlerdir. ${ }^{83}$ Etrüskler ataerkil Yunan panteonunun aksine tanrı ve tanrıçalarını hiçbir zaman tek düze betimlememiş ve onların yaşlarını, görüntülerini, cinsiyetlerini farklı şekillerde yansıtmışlardır. Genellikle çift olarak betimlenen Etrüsk tanrıları arasında bazen ensest çağrışımlar yapacak motifler de kullanılmıştır. Bu, Etrüsk sanatının hareketli doğasının bir ürünüdür. ${ }^{84}$ Yunan ve Roma anlayışının aksine Etrüsk tanrı ve tanrıçalarının genellikle çift olarak tasvir edilmesi ve tanrısal aile birliğine vurgu yapılması Etrüsk dinine ait bir unsurdur. Panteonda tanrıçalar çok önemli konumlara sahiptir ve her zaman çocuğunu besleyen anne imgesiyle resmedilmişlerdir. Bu durum Etrüsklerin sosyal hayatına yansımış, dönemin Yunan ve Roma kültürünün aksine kadına büyük özerklik veren aile yapıları İtalyan tarihine damgasını vurmuştur. ${ }^{85}$

Etrüsk teolojisinden etkilenerek dinî altyapısını oluşturan bir halk varsa, Romalılardır. Her ne kadar Dumézil Etrüsklerin Roma üzerindeki etkisinin abartıldığını ve Romalıların Hint-Avrupa kökenli tabiatı nedeniyle zaten orijinal bir dinî anlayışa sahip olduğunu iddia etse de ${ }^{86}$, Etrüsklerin birçok konuda olduğu gibi dinî hususta da Roma’ya öncülük ettiği tarihî bir gerçektir. Etrüsklerdeki kutsalı anlama ve profanı kutsallaştırma konusundaki ezoterik kabiliyet, Yunanlılarda olmadığı için Romalılara dini anlama ve yorumlamada öncülük etmiş̧ ve Orfizm ve Pythagorasçılık gibi felsefi kökenli gizem tarikatlarının kurulmasını sağlamıştır. ${ }^{88}$ (Önsöz'den).

Azra Erhat, A. Kadir (çeviri ve notlar), Homeros - İlyada, TİB Yayınları, İstanbul 2015, s. xxix

Bonfante-Swaddling, a.g.e., s. 15; Prof. Dr. Tulunay'dan aktarım, Türkkan, a.g.e., s. 227.

Simon, a.g.m., s. 45; Bonfante-Swaddling, a.g.e., ss. 17, 123.

Bonfante-Swaddling, a.g.e., ss. 83, 85.

Bonfante-Swaddling, a.g.e., ss. 81-83, 86; Türkkan, a.g.e., s. 162.

Dumézil, a.g.e., s. 625.

Izzet, a.g.e., s. 11.

Diogenes Laertios, Ünlü Filozoflarn Yaşamlan ve Öğretileri, çev. Candan Şentuna, YKY Yayınları, 
Etrüsk panteonu, Etrüsk kozmik algisına uygun olarak gök/olimpik, yer/kült ve yer altı tanrıları olarak üçe ayrılır. Göksel tanrıların zirvesinde Tin/Tinia (Yun. Zeus; Lat. Jüpiter), eşi "gençlik tanrıçası" Uni (Hera/Juno) ve Menerva (Athena/ Minerva) üçlemesi bulunur. Bu üç tanrı, Etrüsk devletinin resmi tanrıları olup tapınakları her Etrüsk şehrinin kale surlarında yer alır. ${ }^{89}$ Bu üçlemenin emaresi olarak Etrüsk Tarkanlan (Tarquinler) Roma-Capitoline Tepesi’nde bir tapınak inşa etmişlerdir. Bu tapınak, sonradan Roma'nın simgesi haline gelmiştir. Romalılar bu uygulamayı benimsemişler ve diğer şehirlerine de uygulamışlardır. ${ }^{90}$

Etrüsk panteonunun zirvesinde "gün ışığı" anlamına gelen Yüce Tanrı Tin/ Tinia bulunur. ${ }^{91}$ "Tin/Tinia" adı, Tanr anlamındaki Sümerce tin-dingir, Türkçe tengri ve Çince tien kelimeleriyle aynı etimolojiye sahiptir. ${ }^{92}$ Zaten bu tanrı adının türediği tin kelimesi, "ruh" anlamına gelir ${ }^{93}$ ki bu da antik dönemde insanların tanrılarına kutsal ruhlar olarak taptıkları animist ve ezoterik anlayışla örtüşür. Tinia kimi zaman dişil halde Thanr/Thalna olarak tezahür eder ve onun bu yansıması tanrının sevgilisi olarak ifade edilir. ${ }^{94}$ Tinia, kimi zaman Yunan dinindeki gibi elindeki yıldırımıyla kimi zaman sakallı bir ihtiyar, kimi zaman da bir genç olarak betimlenir ${ }^{95}$ ve gün doğarken onu karşlamak ve tazimde bulunmak üzere yüksek tepelere çıkılarak dualar edilir. ${ }^{96}$ Tinia' nın gerek cinsiyet gerekse tecelli olarak farklı tezahürleri, Etrüsklerin tabiattaki doğum (oluş), ölüm (bozuluş) ve bereket (yaratılış) gibi fenomenlerin kutsallığını ifade etmek için kullandıkları din dilidir. Her şeye rağmen Tinia, tek tanrılı dinlerin Yüce Tanrısı olan Allah/Yahve gibi ne eşsiz yaratıcı ne de kadiri mutlaktır. ${ }^{97}$ Çünkü Thalna'nın diğer versiyonu olan Eş-Ana Tanrıça Uni ve Hikmet Tanrıçası Menerva da oluş-bozuluş döngüsüne katıldığından tapımın önemli unsurlarıdır. ${ }^{98}$ Üç tanrının bir bütün oluşturarak yaratılışın gerçekleştiği söylenebilir.

İstanbul 2017, VIII/1.

89 Keightley, a.g.e., s. 504; Ağasıŏ̆lu, a.g.e., s. 46.

90 Bonfante-Swaddling, a.g.e., s. 102.

91 Keightley, a.g.e., s. 504; Briquel, a.g.m., V, 2870-2871; Bonfante-Swaddling, a.g.e., s. 133.

92 Türkkan, a.g.m., s. 417.

93 Türkkan, a.g.e., s. 154.

94 Stoddart, a.ge., s. 191; Ağasığlu, a.g.e., s. 51

95 Keightley, a.g.e., s. 504; Briquel, a.g.m., V, 2870-2871.

96 M. Ünal Mutlu, "Sümerce ve Etrüskçe Arkaik Türk Dilleridir", Tarihten Bir Kesit: Etrïskler Semроzуити, TTK, 2-4 Haziran 2007 Bodrum, s. 123.

97 Simon, a.g.m., s. 45.

98 Briquel, a.g.m., V, 2871; Bonfante-Swaddling, a.g.e., ss. 17, 81. 
Resmî Etrüsk tanrılarından sonra halkın en çok itibar ettiği tanrıça Turan (Afrodit/Venüs)'dır. Turan, Roma'nın kurucusu iki Etrüsk genci Romus ve Romulus'un mitolojik anneleri kabul edilir. ${ }^{99}$ Tanrıçanın önemine dair diğer mitolojik ima da Etrüsklerin Truva savaşına dayalı olarak anlattıkları Paris'in Karan mitinde Paris'in üç tanrıça arasından Turan’ı seçmesiyle gösterilmiştir. ${ }^{100}$ Bu yüzden Turan, Etrüsk sanatında en çok tasvir edilen ve en çok külte sahip tanrıçadır. ${ }^{101}$ Onun cinsel içerikli tasvirleri, Etrüsklerde korunma amaçlı kullanılırdı. ${ }^{102}$ Etrüskler "prens" anlamına gelen Turan adını, Anadolu'dan göçlerine ithafen en değerli tanrıçalarına isim yapmışlardır. ${ }^{103}$ Aslında Gaia-Hera ("Toprak Ana/Terra Mater"), İnanna ("Göklerin ve Yerin Kraliçesi”) ve Anahita ("Pers Ülkesinin Hanımı”) gibi toprak ve vatan kültüyle ilgili antik tanrıçalar akla gelince, "Etrüsk-eli" anlamındaki Turan'ın bir çeşit kutsal toprak ve vatan kültünü sembolize ettiği söylenebilir. Turan ile Etrurya, Tirhen ve Truva gibi isimler arasındaki etimolojik köken birliği bunun bir delili kabul edilebilir.

Turan'a benzer bir diğer kült tanriça da bereket ritlerini temsil eden "Toprak Ana" adıyla Cel dir. ${ }^{104}$ Diğer kült tanrılar ise; Thesan (Eos/Aurora), güneş tanrısı Usil/Catha (Helios), ay tanrıs1 Tiur, orman tanrisı Selvans (Silvanus)'trr.

Etrüsklerin tazim gösterdikleri göksel tanrılar arasında su ve deniz tanrısı Nethuns (Poseidon/Neptunus), Apulu (Apollon/Apollo), Fufluns (Dionysos/Bacchus), Aritimi (Artemis), savaş tanrısı Laran (Ares), nalbant tanrısı Setlans (Hephaistos/Volcanus), Vei (Ceres/Demeter) ve haberci tanr//tanrilarm habercisi Turms (Hermes/Mercurius) sayllabilir.

Etrüsklerde yer altı tanrılarının başında Aita (Hades/Pluto) gelir. Aita, soylu bir görünüşe sahiptir ve kurt postundan bir başlık giyer. ${ }^{105} \mathrm{O}$ ve eşi Phersipnai-Culsu

99 Ağasığlu, a.g.e., s. 27.

100 Paris'in Kararı miti özetle şöyledir: Savaş tanrıçası Eris, davet edilmediği tanrılar düğün alayının ortasına "En Güzele" yazılı altın bir elma atınca, Uni, Menerva ve Turan bu unvanın sahibi olmak için kavgaya tutuşurlar. Tanrı Tinia tanrıçalardan birini seçmesi için Paris’i seçer. Üç tanrıça da Paris'e kendisini seçmesi için vaadlerde bulunur. Fakat bunlardan sadece Turan'ın "Helen'e sahip olma" vaadi Paris'in dikkatini çekince yarışmayı Turan kazanır. Ayrıntılı bilgi için bkz; Bonfante-Swaddling a.g.e., ss. 20-24, 134-135.

101 Bkz; Simon, a.g.m., ss. 47-52.

102 Bonfante-Swaddling, a.g.e., s. 90.

103 Türkkan, a.g.m., I, 417; A ğasığlu, a.g.e., s. 52.

104 Briquel, a.g.m., V, 287 1; Ağasıŏ̆lu onun bir rüzgâr tanrısı olduğunu belirtir. Bkz. Ağasığlu, a.g.e., s. 48.

105 Etrüsklerde kökeni ifade eden kurt totemi aynı zamanda ölümü de ifade eder. Yani kurt Etrüsk- 
(Persephone/Proserpina) tahtlarından öte dünyayı yönetirler. ${ }^{106}$ Diğer bir yer altı tanrısı da ölüm tanrısı Satre (Saturn)'dir. Fakat kimilerine göre Satre bir hasat tanrısıdır ve onun adına Roma döneminde bir bayram bile tayin edilmiştir. ${ }^{107}$

Diğer yandan diğer antik dinlerde olduğu gibi Etrüsklerde de yarı tanrılar veya tanrılaştırılmış kahramanlar vardır. Bunların başında Herkle (Herakles/Hercules) gelir. Yine Tinas Clinïar (Dioskouroi/Dioscuri), Pultuce (Polydeukes/Pollux) ve Castor (Kastor/Castor) da diğer yarı tanrılardır. Yanı sıra Etrüskler de baskın bir melek ve şeytan inanışı vardır. Melekler ve şeytanların ikincil tanrılar olduğuna inanılır ve kanatlı olarak betimlenir. Vanth en çok tazim gören melek iken, Kharu ve Tukhulka en çok korkulan şeytanlar arasında yer alır. Şeytan tapımı Etrüsklerde pesimizmin arttığı çöküş evresinde çok baskın bir kült olarak yer aldığından bir bakıma medeniyetin çöküşünün dinsel işareti olarak da görülebilir. ${ }^{108}$

\section{b. Etrüsk Dininde Peygamberlik ve Etrusca Disciplina}

Etrüsklerin kehanete ve peygamberliğe dayalı din tasavvuruna inandıklarını söylemiştik. Bunun en belirgin göstergesi, Etrusca Disciplina denen Etrüsk kutsal metinleridir. Bu kutsal metinler, Etrurya ve Latin dünyasının bütün kozmolojik algısını, ritüellerini, uygulamalarını ve ahlak kurallarını içermesi bakımından Etrüsklerin "kültürel miras"1dır. ${ }^{109}$ "Bilim, bilimsel öğrenim sistemi ve doktrin" anlamlarına gelen disciplina kelimesi ${ }^{110}$, Etrüsklerin din ve kutsal dedikleri olgudaki bilimsel bakış açısını ve sistemli düşünme tarzını vurgular. Tamamıyla kutsallık anlayı̧ıı ve ritüellerle donanmış Etrüsk dini, aslında kutsal bilim ya da bilimsel din ${ }^{111}$

ler için başlangıç ve sonun sembolüdür. Ağasığlu, a.g.e., s. 47.

106 Bonfante-Swaddling, a.g.e., s. 125.

107 Livy, The Early History, Kitap II, s. 108, 34. dipnot.

108 Ağasığlu, a.g.e., ss. 46, 55.

109 Fay Glinister, "Vailed and Unvailed: Uncovering Roman Influence in Hellenistic Italy", Votives, Places and Rituals in Etruscan Religion, edt.by. Margarita Gleba, Hilary Becker, Brill, Boston 2009, s. 204, 45. Dipnot; Stoddart, a.g.e., s. 66.

110 Lewis Ramshorn, Dictionary of Latin Synonymes, Boston 1839, 354, s. 171; Oxford Latin Dictionary, Oxford University Press 1968, s. 550.

111 Bu, Seyyid Hüseyin Nasr'ın “kutsal bilim” adını verdiği şeydir. Nasr'ın "İslamî Bilim” olarak aktardığı ve temelini kadim bilimlere dayandırdığı kutsal bilimin gayesi, varlıklardaki birliği, aralarındaki karşılıklı bağı göstermek ve kozmostaki bu birlikten hareketle insanı İlahi İlke Birliğ ’ne yükseltmektir. Monist bir anlayışa sahip olduğu görülen "kutsal bilim"e göre tabiat, sembollerle örülü bir metindir ve böyle okunmalıdır. Kutsal metinler ise doğanın 'söz'e dönüşmesinden başka bir şey değildir. Bu bakımdan insanoğluna bilhassa Müslümana düşen, kadim ilimlerin ve tüm dinlerin ortak ilim, vahiy ve hikmet geleneğini dirilterek modernitenin kısır döngüsünden 
denebilecek bir anlayışın en iyi örneğidir. Bu anlayış çerçevesinde derlenmiş bir kutsal metin olan Etrusca Disciplina, hiçbir zaman Etrüsklerce insan ürünü kabul edilmemiştir. Bu metinler kendilerine Tages ${ }^{112}$ ve Veçu adı verilen peygamberlere kadim devirlerde Tanrı tarafından vahyedilmiş ilahî kelamdır. ${ }^{133}$ Yunan ve Latin kaynaklar, Etrüsk peygamberler hakkında pek çok söyleyiş kaydetmişlerse de bunların orijinal kaynakları maalesef günümüze ulaşmamıştır. ${ }^{114}$

Etrüsk peygamberlik anlayışının merkezinde Tages miti yer alır. Bu mite göre bir gece gökten düşen bir ylldız, yerden bitki gibi bebek Tages'i bitirmiş, bebek yaşlı bir bilge gibi dile gelmiş ve Etrusca Disciplina'yı Etrüsk' ün kurucu atası ve ilk kahini olan Tarkan (Tarchon)'a şifahen aktarmıştır. ${ }^{115}$ Tages kimilerine göre bu bilim dininin düsturlarını aktardıktan sonra yok olmuşken kimilerine göre de büyüdügünde Etrurya'yı ilk kuracak olan Tarkan'ın yani ilahî kelamı Etrüsk halkına aktarmakla görevlendirilmiş bir peygamberin kendisidir. Kısaca değişik versiyonları olan bu mit, dinler tarihçileri tarafindan "yaşlı bebek bilge" motifiyle süslenmiş bir vahiy anlatımı kabul edilir. ${ }^{16}$ Diğer yandan antik Etrüsk kenti Pian di Civita'da yapılan kazılarda, epilepsi sebebiyle ölen 7-8 yaşlarındaki çocuk cesedi üzerinde yapılan araştırmalar, çocuk mezarın kült merkezine dönüşmesinden hareketle bu çocuğun Tages kabul edilmiş olabileceği düşündürtmüştür. ${ }^{17}$

Bir diğer Etrüsk peygamberi de Melek Veçu (Vegoia/Begoe)'dur. Veçu'nun asırlarca Apollon Tapınağı'nda korunan yıldırım kitabının yazarı olduğu ve burada yaratılışın sırlarına dair bilgiler aktardığı düşünülür. Bu sebeple yıldırımlar kitabına Veçu'nun Kitabı (Libri Vegoici) da denir. Tages ve Veçu'nun dışında Etrüsklerin peygamberlik atfettiği başka karakterler de mevcuttur. ${ }^{18}$

kurtulmaktır. Yani kadim ilimlere dayalı bilimsel anlayışı ve dini aynı potada eritebilmektir. Ayrıntılı bilgi için bkz. Seyyid Hüseyin Nasr, Bilgi ve Kutsal, çev. Yusuf Yazar, İz Yayıncllı, İstanbul 2013.

112 Latince Tages adı, Etrüskçede - $\mathrm{g}$ sessizi olmaması sebebiyle -ç'ye dönüşerek Taçe, Taçu şeklinde de okunabilir. Bkz. Nancy Thomson de Grummond, "Prophets and Priests", edt.by. Nancy Thomas de Grummond-Erica Simon, University of Texas Press, Texas 2006, s. 27.

113 Schullard, a.g.e., s. 30; Francovich, a.g.m., s. 42; De Grummond, "Introduction", s. 1.

114 De Grummond, "Prophets", s. 27.

115 Stoddart, a.g.e., s. 66; De Grummond, "Prophets", s. 27; Tulunay'dan aktarım, Türkkan, a.g.e., ss. 22-226; Ağasıoğlu, a.g.e., s. 36.

116 Briquel, a.g.m., V, 2872.

117 De Grummond, "Prophets", s. 28.

118 Ayrıntılı bilgi için bkz; De Grummond, "Prophets", ss. 30-33. 
Etrusca Disciplina adı verilen dinî-bilimsel öğretiler, ilk kâhin/peygamber Tarkan'ın soyundan gelen kâhinler sinıfi (haruspices) tarafindan telif edilip korunmuştur. Genellikle haruspice/haruspex adıyla bilinen kâhinlerin cepen (cepar), maru (maron)nun yanı sıra, kâhinler gurubunu ifade eden collegium ve marunux spurana cepen şeklinde başka isimleri de mevcuttu. ${ }^{19}$ Veçu'dan şifahen bu kutsal bilimi edindiklerine inanılan kâhinler, toplumun en üst katmanını oluştururlardı. Onlar gerek dinî gerekse bilimsel alanda son derece eğitimli kimselerdi. Romalılar, onlara "Büyük Üstadlar” der ve pek çok Romalı, ilahî sırra erişmeleri için çocuklarını bu kâhinlere çırak olarak verirdi. ${ }^{120}$ Kâhinler, Veçu ve Tages'den devraldıkları ilahî vahyi kayda geçirdiler ve büyük gizlilikle kendi torunlarına aktardılar. Kâhinliğin özel eğitim ve kabiliyetin yanı sıra kutsal bir soy aracılığıyla iletilen vehbî ve kesbî doğası olduğu söylenebilir. Bu bakımdan kâhinliğe soy aktarımıyla muhafaza edilen, özel yeteneklere ve sırlara sahip "kutsal bilim adamları topluluğu” demek yanlış olmaz. ${ }^{121}$ Bu, Orta Asya kamlığının, Mısır rahiplik geleneğinin ve Sümer-Babil'de "Kaldeliler" olarak bilinen din-bilim adamlığının Etrurya'ya yansımış hali gibi anlaşlabilir.

Kâhinlerin Etrurya'da icra ettikleri pek çok görev arasında en öncelikli olanı, tanrılarla Etrüsk halkı arasındaki iletişimi sağlamaktı. Onlar hem tanrılarla insanlar arasında hem de halk bünyesinde arabulucu idiler. Aynı zamanda toplumdaki bütün ibadet ve ritüelleri de yürütüyorlard1. ${ }^{122}$ Diğger yandan kâhinler, Etrüsklerin teokratik siyaset anlayışına uygun olarak, sadece dinî bir figür olmayıp siyasette de önemli görevler icra eden politikacılardı. Bu sebeple onlar siyasi arenadan hiçbir zaman ayrı düşünülemezler. ${ }^{123}$

Kâhinler kastının en orijinal özelliklerinden biri, çağdaşları Yunanlılar gibi "kutsal"a mania ${ }^{124}$ vasıtasıyla değil, birtakım ritlere dayalı ilahî komutların yerine getirilmesiyle ulaşmalarıdır. Bir diğer özellik de onların kutsal anlayışlarını maddi âleme dayamış olmalarıdır. Onlar gnostik din ve felsefenin küçümsediği dünyevî hayatı ve "madde"yi bilimsel bir anlayışla yorumlayarak "İlâhî Olan"a ulaşmayı

119 De Grummond, "Prophets", s. 33.

120 De Grummond, "Introduction", s. 2.

121 Hilary Becker, "The Economic Agency of the Etruscan Temple", Votives, Places and Rituals in Etruscan Religion, edt.by. Margarita Gleba, Hilary Becker, Brill, Boston 2009, s. 93.

122 Glinister, a.g.m., s. 203.

123 De Grummond, "Prophets", s. 34.

124 Mania, tanrısal ruhun insan bedenine geçerek kişiye tanrılar ve fenomenler âlemi arasında iletişim kurma yeteneği kazandırmasıdır. 
önemsemişlerdi. Bu onların en belirgin dinî yöntemleridir. Çünkü tanrı/lar, insanlara fenomenler aracilığıyla işaretler gönderdiği için kutsalı anlamanın yolu onlara göre maddî âlemi anlamaktan geçer. Etrüsk dönemi aynalarında kâhinlerin organ incelemeleri ve kutsalı elde etme çalışmalarına dair motifler, kutsal kelam Etrusca Disciplina’nın empirik bir anlayışla kompoze edildiğinin göstergesidir. ${ }^{125}$

Evren ve öte dünyanın sırlarını açıklayan Etrusca Disciplina hakkındaki çalışmalar, en erken MÖ. I. yüzyıla uzanır. Bu yüzyılda Etrüsk kökenli Tarquitius Priscus Latinceye çevrilen kutsal metinleri toplamış fakat Etrüsklere uygulanan soykırım sebebiyle yirmi cildi bulan eserlerin neredeyse tamamı yok olmuştur. ${ }^{126}$ $\mathrm{Bu}$ sebeple biz Etrüsk din ve kutsal metinleri hakkındaki bilgilere sadece Roma kaynaklarından ulaşabiliyoruz. Aktarımlar genellikle Tannlarn Doğası (De Natura Deorum) adlı eseriyle Cicero, onun çağdaşı Volaterrae, rüyalar ve kehânetler hakkında araştırma yapan Nigidus Figulus ve Vecu'nun peygamberliği hakkında bilgiler aktaran Cornelius Labeo vasitasıly edinilmektedir. Bu yazarların ortak noktası kutsal yazmalardaki çeşitli ritüelleri, tanrılardan gelen mesajları yorumlama ve onları yerine getirmeye dair yaptıkları açıklamalardır.

Etrüsk kutsal metinleri üç kısma ayrılır: Gökyüzü hareketleri, hava durumu ve ı̧̧ı̆̆ın mahiyetine yönelik bilgiler içeren Kildırm Kitaplar (Libri de Fulguratura); kurban organlarından edinilen ilahî sırları anlatan Kehânet Kitaplan (Libri Haruspicini) Fatales). Bu iki kitap Etrüsklerin kehanet ve ilahî sırları elde etmeye verdikleri önemi ortaya koyar. Üçüncü kitap ise, ilk iki kitaptaki alâmetlere bağlı olarak kutsalın tezahürü için gerçekleştirilen ritüel ve hükümleri kapsayan Ritïel Kitaplan (Libri Rituales)'dır. ${ }^{127}$ Ağasıŏlu, bu kitaplara mucizeleri anlatan Libri Fatales ve ölümden sonraki hayatı betimleyen Libri Acheruntici' yi de ekleyerek sayıyı beşe çıkarır. ${ }^{128} \mathrm{Fa}-$ kat bu son iki kitap genellikle diğerlerinin bölümleri kabul edildiğinden biz ilk kategoriye göre açıklama yapacağız.

\section{Libri Fulgulares/Yıldırım Kitapları}

Aslında Etrüskler yıldırımlarla ilgilenen tek toplum değildir. Hava durumu ve ylldırımlar kutsala ulaşma hususunda tüm antik toplumların bilgi kaynağıdır. Gök

125 Briquel, a.g.m., V, 2872.

126 Ağasığlu, a.g.e., s. 19.

127 Francovich, a.g.m., s. 42; De Grummond, "Introduction", ss. 1-2; Briquel, a.g.m., V, 28722873.

128 Ağasığlu, a.g.e., ss. 38-39. 
olaylarının incelenmesi bile baş̧ı başına analitik düşünme kabiliyeti gerektiren bilimsel bir gözlemdir. ${ }^{129}$ Etrüskleri diğer toplumlardan ayıran, fenomeni kutsalın tezahürü kabul eden bir nazariyeyle incelemeler yapmaları ve bu şekilde kutsala ulaşmayı hedeflemeleriydi. Çünkü onların inancında yıldırım başlı başına Tanrı'nın sesini ve mesajını içeren doğal bir olguydu ${ }^{130} \mathrm{Bu}$ sebeple onlar yıldırımın şekli, rengi, toprağa düşüş yeri, zamanı ve etkilerinden yola çıkarak doğanın çalı̧̧ma şeklini inceliyorlar bu sayede evrensel yasayı çözmeye çalışıyorlardı. Kendilerine fulgurator denen yıldırım kâhinleri, içine tanrıların niyeti gizlenen fenomenlerin kodlarını kırmaya uğraşılardı. ${ }^{131}$ Etrüsk kadını özellikle kehânette çok mahirdi. Bir kadın, kocasına sarıldığı anda onun gelecekte yaşayacağı durumları kendisine haber verebilirdi. ${ }^{132}$ Roma tarihinde kadınların bu özelliğine dair bilgilerin hususiyetle anlatılması, kurumsal ataerkilliğin mimarı olan Yunan ve Romalılara Etrüsk kadının sosyal hayattaki üstün konumu oldukça tuhaf gelmiş olsa gerektir. ${ }^{133}$

Antik birçok toplumdaki gibi en yüce tanrıya atfedilen hava ve ylldırım tanrısı olma sıfatı, Etrüsklerde de baş tanrı Tinia’ya verilmiştir. Yıldırımın üç farklı özelliğini Tinia’ya atfeden Etrüsklere göre yıldırımın en güzel şekli onun insanoğluna sunduğu cömertlik ve bolluk anlamına geliyordu. ${ }^{134}$ Çünkü Tinia'nın yıldırımları, yağmur ve bereketin habercisiydi. Yıldırımın korkutucu ikinci şekli, tanrılar konseyinden çıkan kötü kaderin işaretiydi. Hiçbir şekilde bilinmeyen üçüncü türü ise tanrılar konseyi kararı uyarınca Tinia'nın dünya düzenini değiş̧ireceği anlamına gelirdi. Etrüsk icadı olan saecula hesabı da bu inanca dayandırılmış, her toplumun ve dünyanın kaderi ortalama 120 ylllı saeculalara ayrılarak bu hesaba göre Tinia’nın düzen değişikliği açıklanmaya çalışılmıştır. İnanca göre değişim dö-

İlginç olan Etrüsklerden yirmi beş asır sonra bile gök olaylarının çeşitliliği ve kesin olarak bilinemezliğinden yola çıkılarak ortaya çıkan Kuantum Bilimi ve Kaos teorileridir. Demek ki antik toplumlar modernleşme ile yerleşen genel geçer anlayışa dayalı bilim anlayışından ziyade kuantuma dayalı bilim anlayışını kabul ediyorlardı. Gök olaylarından yola çıkarak kuantum fiziği ve kaos teorileriyle ilgili ayrıntılı bilgi için bkz; James Gleick, Kaos (Kaosun Kutsal Kitabr), Alfa Bilim Yayınları, çev. İlkay Alptekin Demir, İstanbul 2016.

Mutlu, a.g.m., s. 123.

131 Schullard, a.g.e., s. 31; Ağasığlu, a.g.e., s. 43.

132 Livy, The History, s. 51.

133 Bugün Batı dünyasında semitik dinlerin ataerkilliğin uygulayıcısı ve meşrulaştırıcısı olduğuna dair yürütülen yanlış yargının aksine, pek çok kaynak kurumsal ataerkil zihniyetin Yunan ve Roma sayesinde dünyaya kök saldığını belirtir. Ayrıntılı bilgi için bkz; J. Jakob Bachofen, Söylence, Din ve Anaerki, çev. Nilgün Şarman, Payel Yayınları, İstanbul 2013; Reay Tannahill, Tarihte Cinsellik, çev. Sinem Gül, Dost Kitabevi, Ankara 2003. 
nemlerinde sayıları, cinsiyetleri ve özellikleri bilinmeyen gizemli tanrılar tezahür eder ve yeryüzünün kaderini etkileyen çok büyük olaylar meydana getirirlerdi. Bu dönemler bozuluş-yeniden oluş zamanlarıdır. ${ }^{135}$

\section{Libri Haruspicini/Kehânet Kitapları}

Kehânet kitapları, hem antik halklarca iyi bilinen hem de Etrurya'ya has kehanet yöntemlerini kapsar. Hepatoskopik denen kanı tanrılara sunulan kurbanların iç organlarından deneysel yöntemlerle sırlara erişmeye dair gözlemler kehânet kitaplarına kaydedilmiştir. Bunlardan birine göre Etrüsk kâhinleri kırk dört parçaya ayırdıkları kurban parçalarının her birinin üzerine Etrüsk tanrılarının isimlerini yazar, ${ }^{136}$ tanrılardan haber alabilmek için bu parçaları dört tarafına tanrı adı nakşedilmiş bir kutuya yerleştirerek onlar üzerinde çeşitli deneyler ve ölçümler yaparlardı. Söz konusu kutulardan biri 1877'de Emilia-Piacenza'da bulunmuş olup hala üzerinde Etrüsk dini ve kutsal kitaplarının aydınlatılması için çalışmalar devam etmektedir. ${ }^{137}$

\section{Libri Rituales/Ritüel Kitapları}

Etrüsk kehanet sisteminin merkezinde olması hasebiyle kurban Etrüsk dininin önemli bir parçasıdır. Kurban, Etrüsklerde sadece tanrılara yaklaşma anlamı taşımaz. $\mathrm{O}$, aynı zamanda kurban vasıtasıyla memnun edilen tanrılara danışma ve onlarla iletişime geçme aracıdır. Bu bakımdan başta kurban olmak üzere bütün ritüeller bilimsel verilere dayalı Etrüsk kehanet sisteminin bir parçasıdır.

Etrüsk ritüel kitapları sadece ritüellere ilişkin hükümleri içeren tek düze eserler değildir. Bu külliyatta yer alan Libri Fatales türü kitaplar, ritüellerin işlevleriyle ilgili önemli bilgiler sunar. Aynı zamanda önceki kitaplarda geniş çaplı ele alınan kehanet ve ilahi iletişim, burada tanrıların alametleri ve fatum olarak açıklanır. ${ }^{138}$ Libri Rituales, şehirlerin kurulması, mabedlerin inşası, savaş ve barış dönemine ilişkin uygulamalar ve sosyal hayata ilişkin geniş çaplı hükümler de içerir. ${ }^{139}$ Kâhinler yönlerini, kutsal metinler ve Etrusca Disciplina'ya göre tayin ederler ${ }^{140}$ ve bir yerle-

135 Schullard, a.g.e., s. 31; Briquel, a.g.m., V, 2872-2873; Stoddart, a.g.e., s. 170.

136 Schullard, a.g.e., s. 31.

137 Briquel, a.g.m., V, 2872-2873.

138 Briquel, a.g.m., V, 2873; Ağasığlu, a.g.e., s. 39.

139 Schullard, a.g.e., s. 31.

140 Ingrid E. M. Edlund, "Ritual Space and Boundaries in Etruscan Religion", The Religion of the 
şim bölgesinin harem sınırlarını (pomerium) buna göre çizerlerdi. ${ }^{141}$ Bir şehrin ve bir tapınağın nereye nasıl yapılacağına da ilahî kelama göre karar verilirdi. ${ }^{142}$ Bütün bunlar, Etrüsklerin günümüzde seküler kabul edilen sosyal, siyasal ve askeri konuları, tanrısal hükümlere göre uygulanması gereken meseleler arasında görmelerinden yani teokratik devlet yapılarından kaynaklanır. Gerek tanrısal iletişimi gerekse onları hoşnut etmeyi amaçlayan birçok Etrüsk ritüeli aynıla sonradan Roma dinine aktarılmıştır. Rivayetlere göre Roma'nın kurucusu Romulus, MÖ. 753'te Roma'yı kurarken böyle ritüelleri uygulamıştır. O, kuruluş gerçekleşmeden önce Etrurya'da bir bilgeyi ziyaret etmiş, bilge de ona şehri kutsamak için sınırları beyaz bir inek ve öküzün sabanıyla (sulcus primigenius) çizmesi gerektiğini açıklamıştır. ${ }^{143}$

Ritüel kitaplarının bir diğer bölümünü de Acheron Kitaph̆̆g (Libri Acheruntici) oluşturur. Ölüler dünyasını anlatan bu kitaplar ${ }^{144}$, cenaze töreninde yapılacak uygulamalar hakkında hükümler içerir. Bu ritüellerde Etrüsklerin yaşam, ölüm ve ölüm ötesine dair inançlarının mantığına ulaşmak mümkündür. Bir kurban töreni ile başlayan ölü ve cenaze törenlerinde, ölünün ruhunu kabul edecek tanrılara kurban kanı ikram edilir. Çünkü Dei Animales (Ruh Tannlan) adı verilen bu tanrıların, öte dünyada yaşam bahşettiğine inanılır. ${ }^{145}$

\section{c. Etrüsklerde Öte Dünya İnanci}

Son yirmi yıldaki yeni arkeolojik bulgulara kadar birçok bilim adamı Etrüsklerde net bir öte dünya inancının bulunmadığını düşünüyordu. Fakat ölüm, kabirler ve Libri Acheruntici/The Books of Acheron isimli eserde yer alan anlatımlardan Etrüsklerde de erdeme dayalı baskın bir öte dünya inancı olduğu saptandı. Etrüsklere göre ölüm bir son değil, sadece yeni bir diyara yolculuktur. Kişi kendisine tanrıların takdir ettiği ömrü tamamlar ve yer altı dünyasına göçer. İyi ruhlar tanrılaşarak atalar diyarına yükselir. Ruh Tannlan (dei animales) adı verilen ata ruhlarının kutsal olduğuna ve tanrılara dönüştüğüne dair inanç ${ }^{146}$ da erdem temelli yükselme

Etruscans edt.by. Nancy Thomas de Grummond-Erica Simon, University of Texas Press, Texas 2006, s. 132.

141 Francovich, a.g.m., s. 43.

142 Jean MacIntosh Turfa, "The Etruscan Brontoscopic Calendar", The Religion of the Etruscans edt. by. Nancy Thomas de Grummond-Erica Simon, University of Texas Press, Texas 2006, s. 188.

143 Briquel, a.g.m., V, 2873-2874.

144 De Grummond, "Introduction", s. 1.

145 Briquel, a.g.m., V, 2874.

146 Ingrid Krauskopf, "The Grave and beyond in Etruscan Religion”, The Religion of the Etruscans, 
anlayışının bir göstergesidir. Yani kişinin öte dünyadaki durumu, tanrılara verdiği öneme ve nasıl yaşadığına bağlıdır. ${ }^{147}$ Kötü ruhlar ise yer altı dünyasında çetin bir yolculuğa çıkarlar. Etrüsklerde yeraltı dünyası, gök ve yer tanrılarının ikametgâhının kutupsal karşıtı olan cehennemi ifade eder. ${ }^{188}$ Burası, sadece bir inanç öğesi değil, aynı zamanda aktif bir hikâyesi olan bir yazgl ve ölünün yeni dünyasıdır. ${ }^{149}$

Etrüsklerin cenaze törenleri ve ölüme dair inanışları hakkında en geniş bilgiyi Etrüsk mezarları katakomptlar ve buralardaki fresk ve gravürler verir. Yeraltı dünyasının başkahramanları bu duvar resimlerinde detaylı şekilde tasvir edilmiştir. ${ }^{150}$ İlginç bir şekilde bu resimlerde Yunan yeraltı dünyasına ait pek çok tanrı ve kahraman ya yok sayılmış ya da şeytani ruh olarak gösterilmiştir. Bu, Etrüsklerin, Yunan mitlerindeki pek çok imge ve yan anlamları kendilerine göre yeniden yorumladıklarının kanıtıdır. ${ }^{151}$ Hatta bu durum Etrüsklerin Yunan inanç sistemini benimsemek şöyle dursun bazı noktalarda reddettiğinin de işaretidir. Dinler tarihinde benzer kavramlara farklı ve zıt anlamlar yükleme anlayışı aralarında dinî, siyasî ve tarihî husumet bulunan toplumlarda (Hinduzim-Zerdüştîlik gibi) sık karşılaşılan bir durumdur. Etrüsklerin atalarını Truva'da katlederek Anadolu'dan kovan Yunanlıların dini anlayışını olduğu gibi kabullenmeleri beklenemez.

Ölüler diyarının efendileri, kurt derisinden başlık giyen Aita (Hades) ve onun yllan saçlı güzel karısı Culsu (Persephone)'dur. ${ }^{152}$ Culsu tasvirlerinde, ölüler ve diriler arasındaki iletişimi sağlayan, öte dünya kapısı Chiusi yi açarak mevtaya Ölüm Krallı̆̆ı’nın yolunu gösteren ve ardından kapıyı kilitleyen tanrıça olarak betimlenir. Bu yolculukta kişiye artık ölüm diyarının dişi demonları eşlik edecektir. ${ }^{153}$ Etrüsk din ve sanat anlayışında öte dünya inancı merkezi rol oynadığından, ölülere rehberlik eden bu demonlara pek çok atıf yapılmıştır. Duvar resimleri genel itibariyle ölüm ve ölüm ötesini şöyle sembolize eder: Ölmek üzere olan bir insanın başında onun ölümünü bekleyen Tukhulka ve Vanth isimli demonlar bekler.

edt.by. Nancy Thompson de Grummond-Erika Simon, University of Texas Press, USA 2006, s. 66.

147 Ağasığlu, a.g.e., s. 41.

148 Bonfante-Swaddling, a.g.e., s. 49.

149 Krauskopf, a.g.m., s. 68.

150 Izzet, a.g.e., s. 16, 87.

151 Bonfante-Swaddling, a.g.e., s. 51.

152 Bonfante-Swaddling, a.g.e., s. 51.

153 Krauskopf, a.g.m., s. 67. 
Tukhulka, kulaklarından yılanlar çıkan, gaga burunlu bir zebani, onun karısı Vanth ise çıplak bedenine yılanlar sarılı kanatlı bir demondur. ${ }^{154} \mathrm{Bu}$ kasvetli betimleme Etrüsklerin ölümü günahların yol açtı̆̆ı kötü bir son olarak algıladıklarını gösterir.

Etrüsklerin öte dünya inancında kötü ruhlar olan zebanilerin baskın rol oynadığına ilişkin bir diğer örnek de karşı kıyıya geçirmek için elinde topuzuyla ölmek üzere olanların başında bekleyen kayıkçı Karun (Kharon/Charon)'dur. Etrüsklerin öte dünya inancını yansitan Acheron'un Kitaplan isimli kutsal kitapta ${ }^{155}$ Karun, baskın bir karakterdir. ${ }^{156}$ Ondan, Homeros'un Odyssey'de da Styx nehrinden ölüleri geçiren bir kişi olarak bahsedilir. ${ }^{157} \mathrm{Bu}$ sebeple birçok araştırmacı Etrüsk öte dünya inancının bariz bir şekilde antik Yunan dininden etkilendiği görüşündedir. ${ }^{158}$ Fakat Etrüsklerin Misır-Fenike orijini göz önünde bulundurulursa bu inancın Yunan'dan alındığı yargısının yeniden tahlil edilmeye ihtiyacı ortaya çıkar. Çünkü antik dünyada öte dünya inancının en baskın olduğu medeniyet Mısır'dır. Bu bakımdan Etrüskler söz konusu mite orijinleri itibariyle zaten sahiptiler denilebilir.

Aristokrat Etrüsk ailelerinin kendileri için öte dünyada rehberlik etmesi ve koruması için sanatkârlara fresklerle süslü mezarlar siparişi vermeleri ${ }^{159}$ bu betimlerin onlar tarafindan sanat değil büyü olarak algılandığını gösterir. Çünkü bu mezarları inşa ettirebilen elit aileler bu dünyada yaşadıkları konforlu hayatı ahirette de sürdürecekleri umudunu taşırlar. Yani onlar, bu resimler sayesinde uhrevi saadetlerini perçinlemiş olurlar. Bu anlayış, Mısır'da öte dünyada kişiye ruh katan ve ona yardımcı olan resim anlayışının yansımasıdır. ${ }^{160}$

Etrüsk sanatında safahatın yanı sıra cezalandırmaya da vurgu yapılır ve iki dünya arasında fiziksel bir sınır olduğundan cehennemden asla kaçlamayacağ1 vurgulanır. Her iki âlem arasındaki bu ontolojik farklılık, kurganlardaki geniş

Briquel, a.g.m., V, 2871.

Krauskopf, a.g.m., s. 66.

Briquel, a.g.m., V, 2871.

Stephan Steingräber, "The Cima Tumulus at San Guilano-An Aristocratic Tomb and Monument for The Cult of the Ancestors of the Late Orientalizing Period", Votives, Places and Rituals in Etruscan Religion, edt.by. Margarita Glebaand-HilaryBecker, Brill, Boston 2009, ss. 125.

Bonfante-Swaddling, a.g.e., s. 48.

Bonfante-Swaddling, a.g.e., ss. 51, 54.

Mısır'da mezarlar kişiye özel resimlerle süslenir. Bu, kişinin resim ne kadar güzelse o kadar güzel bir ahiret hayatı yaşamasını sağlar. Şayet bu resimler bozulursa, kişinin ruhu zarar görerek ebediyen yok olabilir. Bkz. Toby Wilkinson, Eski Mısır, çev. Ümit Hüsrev Yolsal, Say Yayınları, İstanbul 2016, s. 133 
koridorlarda betimlenir. ${ }^{161}$ Sisyphos Taşı adlı frenkste, öte dünya mahkûmlarının, cehennemin sonsuz kuyusuna düşen sisyphos taşını yeniden tepeye taşımakla cezalandırılacağı ve bu işlemin döngüsel olarak sonsuza kadar devam edeceği anlat1lır. ${ }^{162}$

Etrüskler ölülerini gömmeden önce yeraltı mezarının çember şeklindeki dromusunda ${ }^{163}$ bazı ayinler icra ederlerdi. Bu ayinlerde öte dünyaya kabul edilen ölü için dualar okunur ve onun namına yudumlanan şarap toprak zemine dökülürdü. ${ }^{164}$ Bu ayinin amacı, öteki tarafa yeni göçmüş ölünün ruhunu huzura kavuşturmaktır. Çünkü kişinin dünyada olduğu gibi ölüler diyarında da onurlandırılmaya ihtiyacı vardır. Bu yüzden onun için güzel bir cenaze töreni düzenlenmeli ve evindeymiş gibi konforuna özen gösterilmelidir. Bu anlayış, Etrüsklerde ruh-beden düalizminin olmadığı aksine maddi öte dünyaya inanıldığı sonucuna götürmektedir. ${ }^{165}$

Dromusun merkezinde bulunan dikdörtgen sunak üzerine kült objeler konur. Cenaze işlemi esnasında mevta, etrafi rölyeflerle kaplı taş bloğa yerleştirilir. Bu, Etrüskçede "Kutsal taş" anlamındaki baityloi denen musalla taşıdır. Etrüskler, bu taşın, yüce ruhların ve yeraltı tanrılarının gök bineği olduğuna inanırlardı. Arkeologlar icra edilen ayinleri, kurgan tipi mezarları ve piramit desenleri, Etrüsklerin arkaik Doğu ve Yakındoğu kökene ait bir toplum olmalarıyla izah etmişlerdir. ${ }^{166}$ Diğer yandan Etrüskler Villanovon kültürden de etkilenmişlerdir. Etrurya döneminden kalma 6322 mezarın bulunduğu katakomptlar, Etrüsklerde gömme âdetinin yanı sıra ölü yakma töreninin de bulunduğunu göstermiştir. Çünkü demir çağından beri Villanovon kültürde ölülerin yakıldığı bilinmektedir. Kimi Etrüskoloğa göre ölü yakma âdeti tüm halk için değil sadece Etrüsk Tarkan ve asilzadeleri için uygulanan üst düzey bir cenaze töreniydi. ${ }^{167}$ Etrüsklerde her iki cenaze ritinin

161 Izzet, a.g.e., s. 93.

162 Bonfante-Swaddling, a.g.e., ss. 51-53.

163 Dromus: Yer altı mezarlarının giriş kısmındaki koridor.

164 Steingäber, a.g.m., s. 125.

165 Krauskopf, a.g.m., ss. 66, 71-72.

166 Izzet, a.g.e., s. 87; Steingräber, a.g.m., ss. 125-130. Ayrıca bkz; Iefke Van Kampen, "Stone Sculpture in the Context of Etruscan Tombs: A Note on Its Position", Votives, Places and Rituals in Etruscan Religion edt.by. Margarita Glebaand Hilary Becker, Brill, Boston 2009, s. 135.

167 Ayrıntılı bilgi için bkz; Marshall Joseph Becker, "Cremation and Comminution at Etruscan Tarquinia in the 5th-4th. Century BCE: Insight in to Cultural Transformations From Tomb 6322", Votives, Places and Rituals in Etruscan Religion edt.by. Margarita Gleba-Hilary Becker, Brill, Boston 2009, ss. 229-248. 
de bulunması, Etrurya'da ölülere ilişkin tören çeşitliliğini ve kişisel tercihi yansıttığı şeklinde düşünülse de ${ }^{168}$, bizce bu aynı zamanda antik toplumlardaki ateş kültünün bir yansımasıdır.

\section{Sonuç}

Truvalıların torunları Etrüskler, antik İtalya'ya damga vurmuş bir halktır. Onları bizler için önemli kılan en önemli unsur, Türkler ve Etrüskler arasındaki genetik akrabalıktır. Etrüsklerin Anadolu'dan ve Avrupa'nın kuzeyinden İtalya'ya geçen Türk kökenli ataları, yerli halkla birleşerek yepyeni medeniyet kurmuşlardır. Bu Batı merkezli tarih anlayışında uzun süre yadsınmış olsa da son dönemlerde yapılan genetik araştırmalarıla kesin olarak ortaya konan bir gerçek haline gelmiştir. Dolayısıyla Etrüskler, Yakındoğu, Anadolu, Yunan ve Roma toplumları arasında köprü kuran, bu kültürleri harmanlayarak kendine özgü yepyeni bir sosyo-kültürel yapı inşa eden senkrektik bir millet olarak görülebilir. Bu halk Roma’yı kurmuş ve günümüze uzanan Avrupa yönetim ve medeniyet anlayışının temelini atmıştır. Son olarak Etrüsk medeniyetinin çağlar sonra Katolik Roma'dan bunalan Avrupa Rönesans'ına ilham olması modern Avrupa'yı anlamada oldukça önemlidir.

Etrüsk dini, Yunan dinine benzer pek çok unsur taşır. Ataları aynı coğrafya için savaşan ve aynı yaşam alanını paylaşan bu iki halk arasında kültürel geçiş olması olağan bir durumdur. Etrüskler, etkileşimde bulundukları tüm toplumlardan edindikleriyle eşsiz bir din anlayışı geliştirmişlerdir. Her ne kadar politeist bir anlayışa sahip olsa da dinlerinin kökenini vahiy ve ezoterik temele dayandırıyor olmaları, peygamberlik anlayışı kıt olan Batı toplumunun bakış açısının gelişmesini sağlamış olmalıdır. Bu din, Yunanlıların materyalist ve ataerkil din algısından oldukça uzaktır. Bunun sonucunda, Etrüsklerde komşularından çok daha medeni ve maneviyatı yüksek bir aile ve sosyal hayat ortaya çıkmıştır. Yine Etrüsklerdeki belirleyici öte dünya vurgusu, halkını erdeme dayalı bir hayat sürmeye ve ölümü estetik ve bilimsel bir olgu olarak kabul etmeye itmiştir.

Son olarak Etrüsk dininin mitik ve ezoterik doğasının yanı sıra bilimsel anlayışa sahip kitabî bir din olduğu söylenebilir. Bu da yaşandığı çağa oranla Etrüsk dinini oldukça modern bir anlayışa sahip kılmıştır. Denebilir ki bilimsel doğasıyla monist bir anlayışa sahip olan Etrüsk dini, genellikle peygamberlik, kutsal kitap ve "ahlakî bir tanrı" anlayışıyla İbrahimî dinlere de yaklaşmaktadır. 


\section{KAYNAKLAR}

Ackerman, Marsha E. Schroeder, Michael J. Terry, Janice, Upshur, Jiu-HwaLo. Whitters, Mark F. (edt. by.) Encyclopedia of World History, Fact on File Publishing, New York 2008.

Ağasığlu (Celilov), Firudin, Etrïsk Türk Bağr, sad. Hüseyin Adıgüzel, Bilge Oğuz Yayınları, Ankara 2013.

Arslan, Ahmet ve diğerleri, "Archeological, Etymological, and Genetic Traces of Migrations Along with Etruscan Migration for Forming European Nations: I. Migrational Traces Was Followed Together with Alphabetical Evolution", Tarihten Bir Kesit: Etrüskler Sempozyumu, TTK, 2-4 Haziran 2007 Bodrum, ss. 65-105.

Ayda, Adile, Etrïskler Türk mü idi?, TKAE, Ankara 1974.

Ayda, Adile, "Etrüsklerin Türklügüne Yeni Deliller", Atlantisliler Sümerler Etriuskler Tïrk mü?, yay. Reha Oğuz Türkkan, Nokta Kitap, İstanbul 2012, ss. 181-188.

J. Jakob Bachofen, Söylence, Din ve Anaerki, çev. Nilgün Şarman, Payel Yayınları, İstanbul 2013.

Becker, Hilary, "The Economic Agency of the Etruscan Temple", Votives, Places and Rituals in Etruscan Religion, edt. by. Margarita Gleba, Hilary Becker, Brill, Boston 2009.

Becker, Marshall Joseph, "Cremation and Comminution at Etruscan Tarquinia in the 5th-4th. Century BCE: Insight in to Cultural Transformations From Tomb 6322", Votives, Places and Rituals in Etruscan Religion edt. by. Margarita Gleba and Hilary Becker, Brill, Boston 2009.

Bernal, Martin, Kara Atena, çev. Özcan Buze, Kaynak Yayınları, İstanbul 2014.

Bloch, Raymond, Etruscan Art, New York GraphicSociety, Milan 1965.

Bonamici, Marisa, "The Etruscan Period", The Land Of The Etrucans, edt. by. Salvatore Settis, Scala Books, Italy 1985.

Bonfante, Larissa-Swaddling, Judith, Etrüsk Mitteri, çev. Birgül Açıyıldız, Phoenix Yayınları, Ankara 2006.

Briquel, Dominique, "Etruscan Religion", Encyclopedia of Religion, by. Lindsay Jones, IInd edition, (1987) 2005. 
Chrisp, Peter, Atlas of Ancient Worlds, DK, New York 2009.

Dumézil, Georges, Archaic Roman Religion With an Appendix on the Religion of Etruscan, trans. by. Philip Krapp, The John Hopkins Univ. Press, Chicago 1996.

De Grummond, Nancy Thomas, "Introduction: The History of the Study of Etruscan Religion", The Religion of the Etruscan, edt. by. Nancy Thomas de Grummond-Erica Simon, University of Texas Press, Texas 2006.

De Grummond, Nancy Thomson, "Prophets and Priests", The Religion of the Etruscans, edt. by. Nancy Thomas de Grummond-Erica Simon, University of Texas Press, Texas 2006.

Doğan, İsmail, "Etrüsk Yazısının Kaynağı: Türk (Göktürk) Yazısı", Tarihten Bir Kesit: Etrïskler Sempozyumu, TTK, 2-4 Haziran 2007 Bodrum, ss. 161-172.

Edlund, Ingrid E. M., "Ritual Space and Boundaries in Etruscan Religion", The Religion of the Etruscans, edt. by. Nancy Thomas de Grummond-Erica Simon, University of Texas Press, Texas 2006.

Ek, Fatma İpek ve Deniz Şengel, "Mısır, Etrüsk, Roma: Piranesi ve Bir On Sekizinci Yüzyll Tartışması”, METU fFFA, 2008/1 (25:1), ss. 27-51.

Ellis, Robert, The Armenian Origin Of The Etruscan, Biblioteca Bodleiana, London 1861.

Erhat, Azra, A. Kadir (çeviri ve notlar), Homeros - İlyada, TİB Yayınları, İstanbul 2015.

Etruscan Glossary, pre. by. Mahir Ünsal Eriş, Ankara 2005.

Francovich, Riccardo, "The Middle Ages", The Land of the Etruscans from Prehistory to the Middle Ages, edt. by. Salvatore Settis, Scala Books, Italy 1985.

Gleick, James, Kaos (Kaosun Kutsal Kitabr), Alfa Bilim Yayınları, çev. İlkay Alptekin Demir, İstanbul 2016.

Glinister, Fay, "Vailed and Unvailed: Uncovering Roman Influence in Hellenistic Italy", Votives, Places and Rituals in Etruscan Religion, edt. by. Margarita Gleba, Hilary Becker, Brill, Boston 2009.

Gürsoy, Akile, "Tarihten Bir Kesit: Etrüskler, Türkiye’de Türk Tarihini Incelemede Antropoloji'nin Katkısı", Tarihten Bir Kesit: Etrüskler Sempozyumu, TTK, 2-4 Haziran 2007 Bodrum, ss. 41-64. 
Herodotus, trans. by. A. D. Godley, Harvard Univ. Press, London 1975, I.

Ildız, Erkan, "Roma Uygarlığının Kökenindeki Doğu Etrüskler”, Atlantisliler Sümerler Etrüskler Türk mü??, yay. Reha Oğuz Türkkan, Nokta Kitap, İstanbul 2012, ss. 189-205.

Izzet, Vedia, The Archeology of Etruscan Society, Cambridge University Press, UK 2007.

Keightley, Thomas, The Mythology of Ancient Greece and Italy, Whittaker Co., Ind edition, London 1888.

Kingsley, Peter, Antik Felsefe Gizem ve Büyü, çev. Kenan Kalyon, Kabalcı Yayınları, İstanbul 2002.

Krauskopf, Ingrid, "The Grave and beyond in Etruscan Religion", The Religion of the Etruscans, edt. by. Nancy Thompson de Grummond-Erika Simon, University of Texas Press, USA 2006.

Laertios, Diogenes, Ünlü Fillozoflarn Yaşamlar ve Öğretileri, çev. Candan Şentuna, YKY Yayınları, İstanbul 2017.

Livy (Livius), Titus, Livy's Hannibal's War, trans. J. C. Yardley and Dexter Hoyos, Oxford World's Classics, Oxford University Press, USA 2006.

Livy (Livius), Titus Patavinus, Rome's Mediterranean Empire, trans. Jane D. Chaplin, Oxford University Press, New York 2007.

Livy (Livius), Titus Patavinus, The Early History of Rome, trans. Aubrey De Sélincourt, Penguin Books, I-V, 2002.

Livy (Livius), Titus Patavinus, The History of Rome, trans. by. Valerie M. Warrior, Hackett Publishing Company, Cambridge 2006.

Memiş, Ekrem, "Etrüsk Kavminin Oluşumunda Troyalılar'ın ve İskitlerin (Sakalar) Rolü”, Tarihten Bir Kesit: Etrüskler Sempozyumu, TTK, 2-4 Haziran 2007 Bodrum, ss. 107-112.

Mutlu, M. Ünal, "Sümerce ve Etrüskçe Arkaik Türk Dilleridir", Tarihten Bir Kesit: Etrüskler Sempozyumu, TTK, 2-4 Haziran 2007 Bodrum, ss. 119-136.

Nasr, Seyyid Hüseyin, Bilgi ve Kutsal, çev. Yusuf Yazar, İz Yayıncılık, İstanbul 2013.

Ogilvie, R. M., Early Rome And The Etruscans, Harvester Press, Fontana, 1976. 
Oxford Latin Dictionary, Oxford University Press 1968.

Pellecchia, Marco, Negrini, Riccardo, Colli, Licia, Patrini, Massimiliano, Milanesi,

Perkins, Philip, "DNA and Etruscan Identity", Etruscan by Definition: Papers in Honour of Sybille Haynes, The British Museum Research Publications, London 2009, pp. 95-111.

Phillips, Charles-Axelrod, Alan, (edt. by.) Encyclopedia of Wars, Fact on File Inc., New York 2005.

Ramshorn, Lewis, Dictionary of Latin Synonymes, Boston 1839, 354.

Rombai, Leonardo, "The Natural Environment", The Land Of The Etrucans, edt. by. Salvatore Settis, Scala Books, Italy 1985.

Scullard, H. H., A History Of The Roman World, Routledge, Vth edition, ABD 1980.

Simon, Erika, "Gods in Harmony-The Etruscan Pantheon", The Religion of the Etruscan, edt. by. Nancy Thomas de Grummond-Erica Simon, University of Texas Press, Texas 2006.

Solmaz, Mustafa, "Biçimbilim ve Sözdizim Açısından Etrüsk Dili”, YYÜ Sosyal Bilimler Enstitüsü (basılmamış yüksek lisans tezi), Van 2005.

Steingräber, Stephan, "The Cima Tumulus at San Guilano-An Aristocratic Tomb and Monument for The Cult of the Ancestors of the Late Orientalizing Period", Votives, Places and Rituals in Etruscan Religion, edt. by. Margarita Gleba and Hilary Becker, Brill, Boston 2009.

Stoddart, Simon K. F., Historical Dictionary of the Etruscans, The Scarecrow Press, UK 2009.

Tannahill, Reay, Tarihte Cinsellik, çev. Sinem Gül, Dost Kitabevi, Ankara 2003.

Turfa, Jean MacIntosh, "The Etruscan Brontoscopic Calendar", The Religion of the Etruscans edt. by. Nancy Thomas de Grummond-Erica Simon, University of Texas Press, Texas 2006.

Van Kampen, Iefke, "Stone Sculpture in the Context of Etruscan Tombs: A Note on Its Position", Votives, Places and Rituals in Etruscan Religion edt. by. Margarita Gleba and Hilary Becker, Brill, Boston 2009.

Wilkinson, Toby, Eski Mısır, çev. Ümit Hüsrev Yolsal, Say Yayınları, İstanbul 2016. 
Türkkan, Reha Oğuz, "Türk Tarih Tezleri”, Türkler Ansiklopedisi, edt. Hasan C. Güzel ve diğerleri, Yeni Türkiye Yayınları, Ankara 2002.

Türkkan, Reha Oğuz, Atlantisliler Sümerler Etrïskler Türk mü̈?, Nokta Kitap, İstanbul 2012.

\section{İnternet Kaynakları}

Copeland, Mel, Work Notes on Etruscan Language:

https://www.academia.edu/1808299/Introduction_to_the_Etruscan_language_-_a_compilation_of_Work_Notes_with_Glossary, 2012. (Erişim Tarihi: $05.12 .2014)$

\section{Global Britannica}

http://global.britannica.com/EBchecked/topic/610528/Tuscany (Erişim Tarihi: 02.12.2014).

New Scientist

http://www.newscientist.com/article/dn11174-on-the-origin-of-the-etruscan-civilisation.html\#.VIBukNKsW8Q. (Erişim Tarihi: 04.12.2014)

New York Times

http://www.nytimes.com/2007/04/03/science/03etruscan.html?pagewante$\mathrm{d}=$ all\&_r=0 (Erişim Tarihi: 04.12.2014)

Elisabetta, Achilli, Alessandro, Bertorelle, Giorgio, Cavalli-Sforza, Luigi L. Piazza, Alberto, Torroni, Antonio, Ajmone-Marsan, Paolo, "TheMystery Of Etruscan Origin: Novel Clues From Bos Taurus Mitochondrial DNA", Proceedings of The Social Society $B$, Royal Society Publishing:

http://rspb.royalsocietypublishing.org/on December 5, 2014, pp. 1175-1179.

Vernesi, Cristiano; Caramelli, David; Dupanloup, Isabelle, Bertorelle, Giorgio, Lari, Martina, Cappellini, Enrico, Moggi-Cecchi, Jacopo, Chiarelli, Brunetto, Castrì, Loredana, Casoli, Antonella, Mallegni, Francesco, Lalueza-Fox, Carles, Barbujani, Guido, "The Etruscans: A Population-Genetic Study", Am 7 Hum Genet, 2004 April;74(4): 694-704; Publishedonline 2004 March 10:

http://www.ncbi.nlm.nih.gov/pmc/articles/PMC1181945/ 
http://www.sciencedirect.com/science/article/pii/S0002929707618941 (Erişim Tarihi, 04.12.2014).

Telegraph

http://www.telegraph.co.uk/news/uknews/1542903/Genes-prove-Herodotus-right-about-Etruscans.html. (Erişim Tarihi: 04.12.2014)

The Guardian

http://www.theguardian.com/world/2007/jun/18/italy.johnhooper (Erişim Tarihi: 04.12.2014). 